DOE/RL-95-99

Rev. 0

\title{
100-FR-3 Groundwater/Soil Gas Supplemental Limited Field Investigation Report
}

Date Published

April 1996

\section{United States \\ Department of Energy \\ P.O. Box 550 \\ Richland, Washington 99352}




\section{DISCLAIMER}

Portions of this document may be illegible in electronic image products. Images are produced from the best available original document. 


\section{CONTENTS}

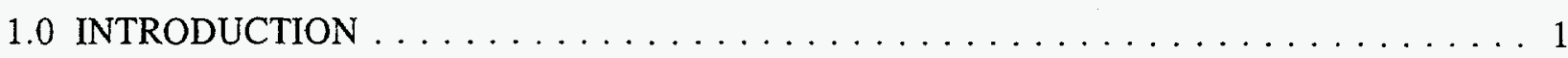

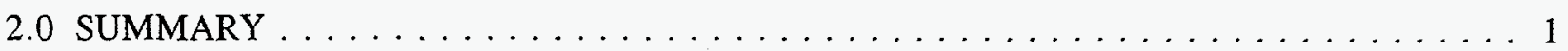

3.0 SITE HISTORY AND DESCRIPTION $\ldots \ldots \ldots \ldots \ldots \ldots \ldots \ldots$

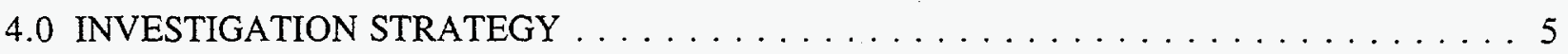

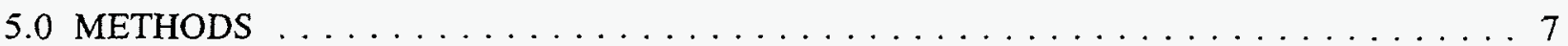

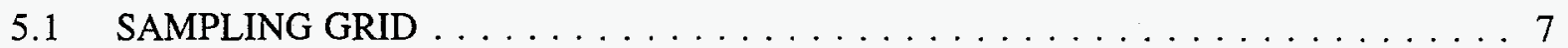

5.2 SOIL GAS SAMPLES $\ldots \ldots \ldots \ldots \ldots \ldots \ldots \ldots \ldots$

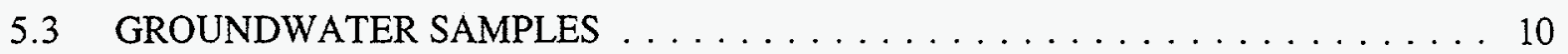

5.4 QUALITY ASSURANCE/QUALITY CONTROL SAMPLES $\ldots \ldots \ldots \ldots \ldots \ldots$

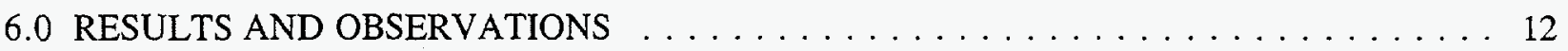

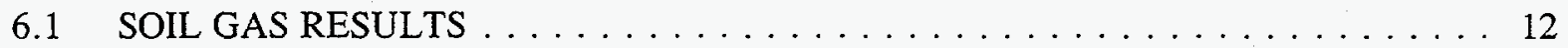

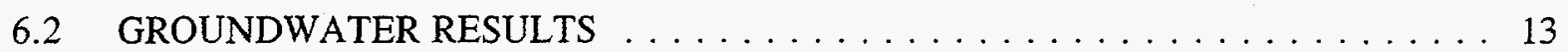

6.3 QUALITY ASSURANCE/QUALITY CONTROL RESULTS $\ldots \ldots \ldots \ldots \ldots \ldots$

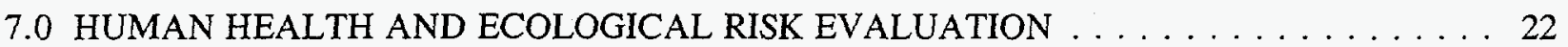

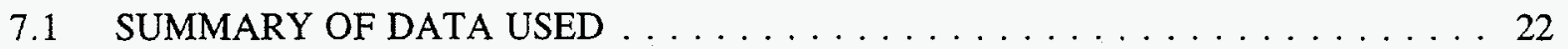

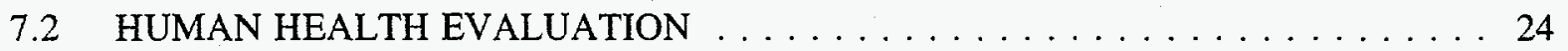

7.2 .1 Overview of Human Health Evaluation Process . . . . . . . . . . . . . 24

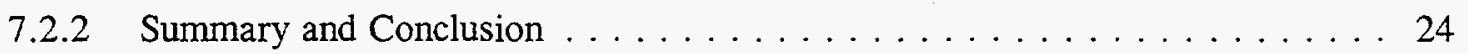

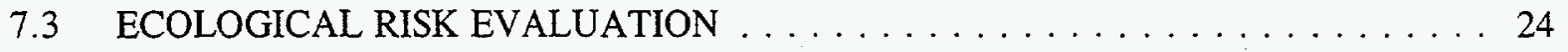

7.3.1 Overview of the Ecological Risk Evaluation Process . . . . . . . . . . . 24

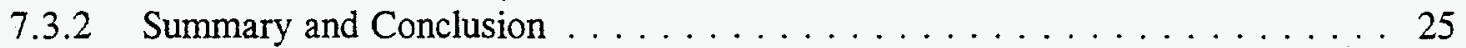

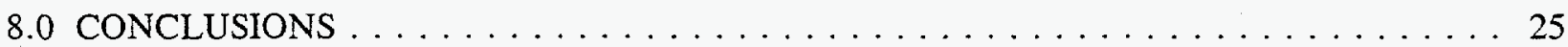

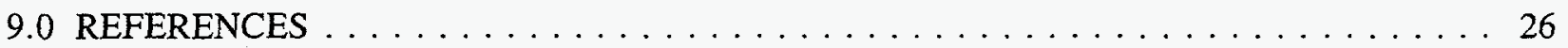

\section{FIGURES}

1. Hanford Site and Major Operations Areas . . . . . . . . . . . . . . . 3

2. 100-F Area and White Bluffs Townsite Region . . . . . . . . . . . . . . . . 4

3. Plot of Historical Trichloroethylene Concentrations Detected in

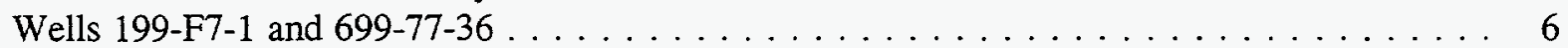

4. 100-FR-3 Groundwater/Soil Gas Supplemental Limited Field Investigation Sampling Grid . . 8

5. Soil Gas Trichloroethylene Concentrations in the 100-F Area/White Bluffs Townsite Region . . 14

6. June 1995 Groundwater Elevations in the 100-F Area/White Bluffs Townsite Region . . . . . . 15

7. Groundwater Trichloroethylene Concentrations in the 100-F Area/White Bluffs Townsite Region . . . . . . . . . . . . . . . . 17

8. Plot of Soil Gas and Groundwater Trichloroethylene Concentrations . . . . . . . . . . . . 18

9. Groundwater and Soil Gas Trichloroethylene Concentrations in the 100-F Area/White Bluffs Townsite Region 


\section{CONTENTS (Continued)}

10. Plot of Shifted Soil Gas and Groundwater Trichloroethylene Concentrations . . . . . . . . 20

11. Plot of Duplicate Soil Gas Sample Trichloroethylene Concentrations . . . . . . . . . . . . 21

12. Plot of Replicate Soil Gas Sample Trichloroethylene Concentrations . . . . . . . . . . . 21

13. Plot of Replicate Groundwater Elevation Measurements . . . . . . . . . . . . . . . 22

14. Plot of Duplicate Groundwater Sample Trichloroethylene Concentrations . . . . . . . . . . 23

15. Plot of Replicate Groundwater Sample Trichloroethylene Concentrations . . . . . . . . . . 23

\section{TABLES}

A-1. Soil Gas Results for the 100-FR-3 Groundwater/Soil Gas Supplemental Limited Field Investigation $\ldots \ldots \ldots \ldots \ldots \ldots \ldots \ldots \ldots \ldots \ldots \ldots \ldots \ldots$

A-2. Groundwater Elevation Measurements for the 100-FR-3 Groundwater/Soil Gas Supplemental Limited Field Investigation . . . . . . . . . . . . . . A-2

A-3. Groundwater Results for the 100-FR-3 Groundwater/Soil Gas Supplemental Limited Field Investigation $\ldots \ldots \ldots \ldots \ldots \ldots \ldots \ldots \ldots \ldots$. . . . . . . . . . .

A-4. Duplicate and Replicate Soil Gas Results for the 100-FR-3 Groundwater/Soil Gas Supplemental Limited Field Investigation . . . . . . . . . . . . . . A A-4

A-5. Replicate Groundwater Elevation Measurements for the 100-FR-3 Groundwater/Soil Gas Supplemental Limited Field Investigation . . . . . . . . . . . . . A A-5

A-6. Duplicate and Replicate Groundwater Results for the 100-FR-3 Groundwater/Soil Gas Supplemental Limited Field Investigation

\section{APPENDICES}

A ANALYTICAL DATA $\ldots \ldots \ldots \ldots \ldots \ldots \ldots \ldots \ldots \ldots \ldots \ldots$ 
DOE/RL-95-99

Rev. 0

\section{ACRONYMS}

$\begin{array}{ll}\text { AWQC } & \text { Ambient Water Quality Criteria } \\ \text { bgs } & \text { below ground surface } \\ \text { cis-1,2-DCE } & \text { cis-1,2-dichloroethylene } \\ \text { COPC } & \text { contaminant of potential concern } \\ \text { DOW } & \text { description of work } \\ \text { DQO } & \text { data quality objectives } \\ \text { EAL } & \text { Environmental Analytical Laboratory } \\ \text { Ecology } & \text { Washington State Department of Ecology } \\ \text { EHQ } & \text { Environmental Hazard Quotient } \\ \text { EPA } & \text { U.S. Environmental Protection Agency } \\ \text { e-tape } & \text { electric tape } \\ \text { FSP } & \text { Field Screening Procedure } \\ \text { GC } & \text { gas chromatograph } \\ \text { GPS } & \text { Global Positioning System } \\ \text { HSRAM } & \text { Hanford Site Baseline Risk Assessment Methodology } \\ \text { HEIS } & \text { Hanford Environmental Information System } \\ \text { HQ } & \text { hazard quotient } \\ \text { LFI } & \text { Limited Field Investigation } \\ \text { LOAEL } & \text { lowest observable adverse effect level } \\ \text { OD } & \text { outer diameter } \\ \text { PCE } & \text { tetrachloroethylene } \\ \text { PE } & \text { polyethylene } \\ \text { ppb-v } & \text { parts-per-billion-volume/volume } \\ \text { ppm-V } & \text { part-per-million-volume/volume } \\ \text { QRA } & \text { qualitative risk assessment } \\ \text { TCE } & \text { trichloroethylene } \\ \text { VOC } & \text { volatile organic compounds } \\ & \end{array}$


DOE/RL-95-99

Rev. 0

\subsection{INTRODUCTION}

In 1993, a Limited Field Investigation (LFI) was conducted for the 100-FR-3 Operable Unit which identified trichloroethylene (TCE) as a contaminant of potential concern (COPC) (DOE-RL 1994). In groundwater samples collected for the LFI, TCE was detected in well 199-F7-1 at a concentration exceeding the U.S. Environmental Protection Agency (EPA) maximum contaminant level $(5 \mu \mathrm{g} / \mathrm{L})$ and Washington State groundwater criteria $(3 \mu \mathrm{g} / \mathrm{L})$. With the concurrence of the EPA and the Washington State Department of Ecology (Ecology), a supplemental LFI was conducted to determine the extent and potential source of TCE groundwater contamination associated with the 100-FR-3 Operable Unit.

This report summarizes the activities and results of the groundwater/soil gas supplemental LFI for the 100-FR-3 Operable Unit. The primary objective of this investigation was to assess the lateral distribution of TCE in shallow ( 3 to $5 \mathrm{ft}$ below the water table) groundwater associated with the 100-FR-3 Operable Unit. The second objective was to assess soil gas ( 3 to 5 concentrations in the study area in an attempt to identify potential sources of TCE and develop a correlation between soil gas and groundwater concentrations. Finally, the third objective of the investigation was to refine the site conceptual model.

\subsection{SUMMARY}

A total of 49 sampling locations were established in an area west of the 100-F Area covering about $2 \mathrm{mi}^{2}$. The sampling locations were established on 1,200-ft centers in a sampling grid. A total of 40 soil gas samples and 41 groundwater samples were collected from specified locations on the sampling grid using a hydraulic probe driver. The data collected also included 41 groundwater elevation measurements. Several duplicate and replicate samples were collected and analyzed from each media to assess data quality. In addition, groundwater samples and elevation measurements were collected from 10 existing groundwater monitoring wells in the region.

The study identified a region of groundwater, containing TCE concentrations in excess of the EPA maximum contaminant level and the Washington State groundwater criteria, southwest of the 100-F Area. The highest TCE concentration detected in the shallow groundwater was $52 \mu \mathrm{g} / \mathrm{L}$ (ppb). The groundwater level measurements collected from each sample point and monitoring wells in the region indicated the groundwater flow direction in the study area was toward the northeast. This regional flow direction and the location of the TCE groundwater plume correlate to the TCE levels detected in well $199-F 7-1$ in the 100-FR-3 LFI.

The study also identified a region of soil gas containing low concentrations of TCE. The highest TCE concentration detected in the soil gas was 77 parts-per-billion-volume/volume (ppb-v). Individual soil gas and groundwater TCE concentrations in samples collected at the same location on the grid did not show a strong positive correlation. However, the general regions where TCE was detected in soil gas corresponded to the general region of shallow groundwater TCE contamination. The data support the hypothesis that TCE may be dissolving into the groundwater as the water moves through a region containing elevated levels of TCE in the vadose zone. This hypothesis is supported by the relative positions of the plumes in relation to the direction of groundwater movement. Evidence of potential surface disposal of liquid waste was observed in the study area. However, no definitive source of TCE contamination was identified. 
A human health and ecological risk assessment based on the groundwater TCE values detected in this investigation concluded that health risks to humans under the frequent-use (residential) scenario are ranked as low. Risks to riparian or aquatic organisms associated with TCE in the groundwater are also anticipated to be low. Consistent with evaluation of other 100 Area groundwater contamination, TCE should not be considered a contaminant of concern in the 100-FR-3 Operable Unit. Existing wells in the study area will be sampled periodically to monitor the TCE concentrations.

\subsection{SITE HISTORY AND DESCRIPTION}

Figure 1 shows the Hanford Site and the location of the major operating areas. The main study area was west of the 100-F Reactor Area located in the northeast portion of the Hanford Site along the Columbia River. Figure 2 is a more detailed map of this region showing the major features, facilities, and roads. The locations of significant historical facilities are also shown in Figure 2. Prior to establishment of the Hanford project in 1943, this region was used primarily for agriculture. Several abandoned farm sites are located in the study area. Domestic wastes are found near these farm sites, usually piles of cans, bottles, and solid wastes that could not be burned or reused. In addition, what appears to be automotive wastes are found at these locations and in the White Bluffs community dumpsites. The town of White Bluffs was located in the northeast part of the study area and was the site of an automotive garage and an ice plant (BHI 1994c).

The White Bluffs region served as a staging area for construction of the $\mathrm{F}$ and $\mathrm{H}$ Reactors from about 1943 to 1948 . The major facilities for this use included material laydown yards, warehouses, maintenance shops, gravel pits, and waste disposal areas. The study region also was the site of several industrial and commercial facilities until about 1965. The American Pipe manufacturing facility and an associated waste disposal facility, the pickling acid cribs, were located in the northwest region of the study area and are shown in Figure 2 (BHI 1994c).

The surficial geology of the study area consists primarily of the gravel-dominated Hanford formation overlying the lower mud unit of the Ringold Formation. The Hanford formation exists from the surface to a depth of 25 to $80 \mathrm{ft}$ and includes occasional sand-dominated intervals. The lower mud unit of the Ringold Formation consists of silt and silty sand. In one portion of the study area, the lower mud unit is $150 \mathrm{ft}$ thick (WHC 1994).

The top of the unconfined aquifer is located within the Hanford formation. The groundwater flow direction is generally eastward toward the Columbia River. The average flow gradient, based on March 1993 water level measurements, is 0.0015 . Slug tests performed in 1992 and 1993 indicated hydraulic conductivities ranged from 30 to $225 \mathrm{ft} /$ day. The lower conductivities appear to be a result of greater silt content in the sediments (WHC 1994).

The vegetation of the study area consists primarily of disturbed shrub-steppe habitat. The old field areas are dominated by cheatgrass and mustards. The disturbed industrial sites are dominated by rabbitbrush and cheatgrass. Relatively undisturbed stands of sagebrush are located along the western border of the study area. 


\section{Rev. 0}

Figure 1. Hanford Site and Major Operations Areas.

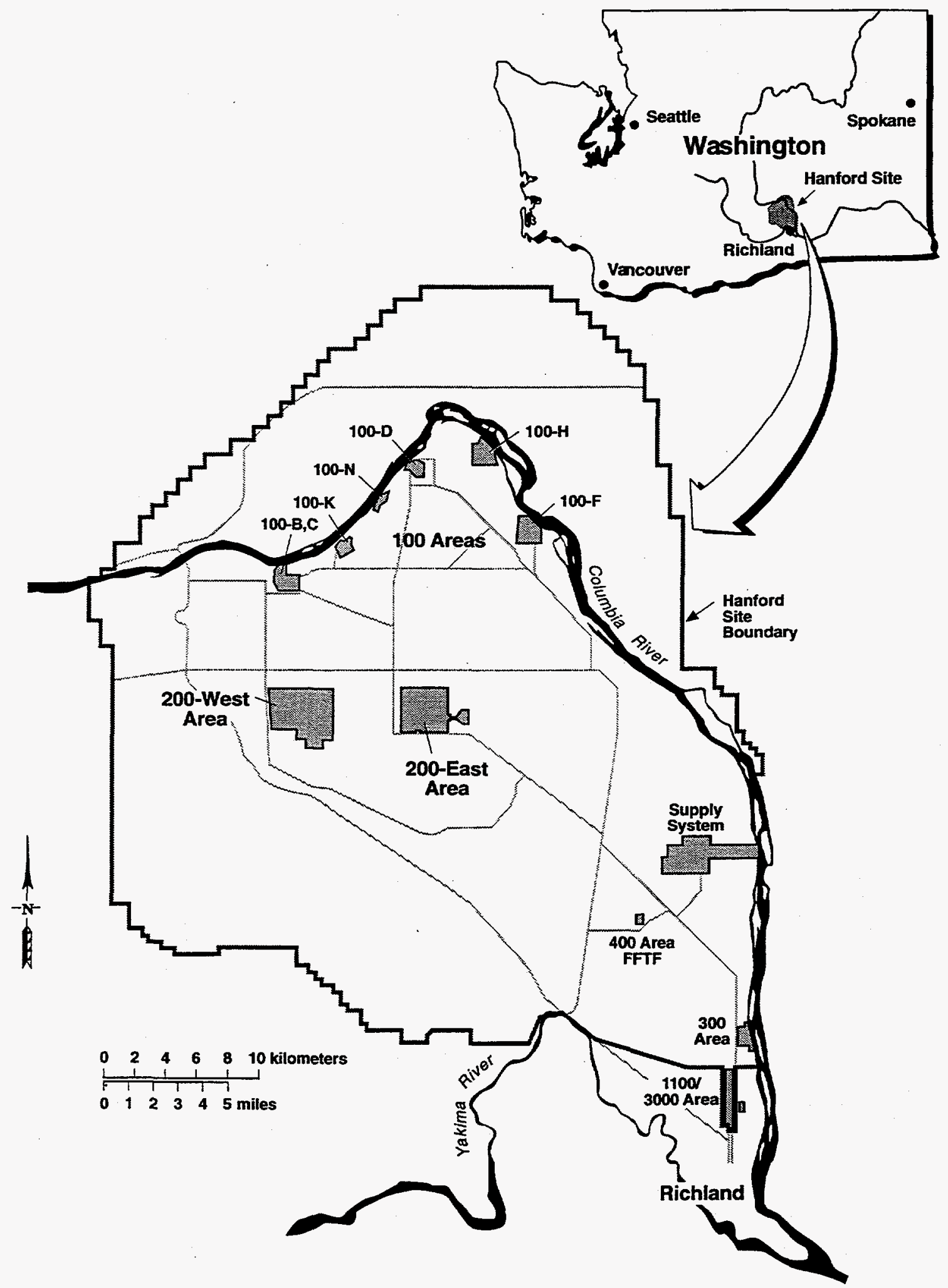

E9508056.2 


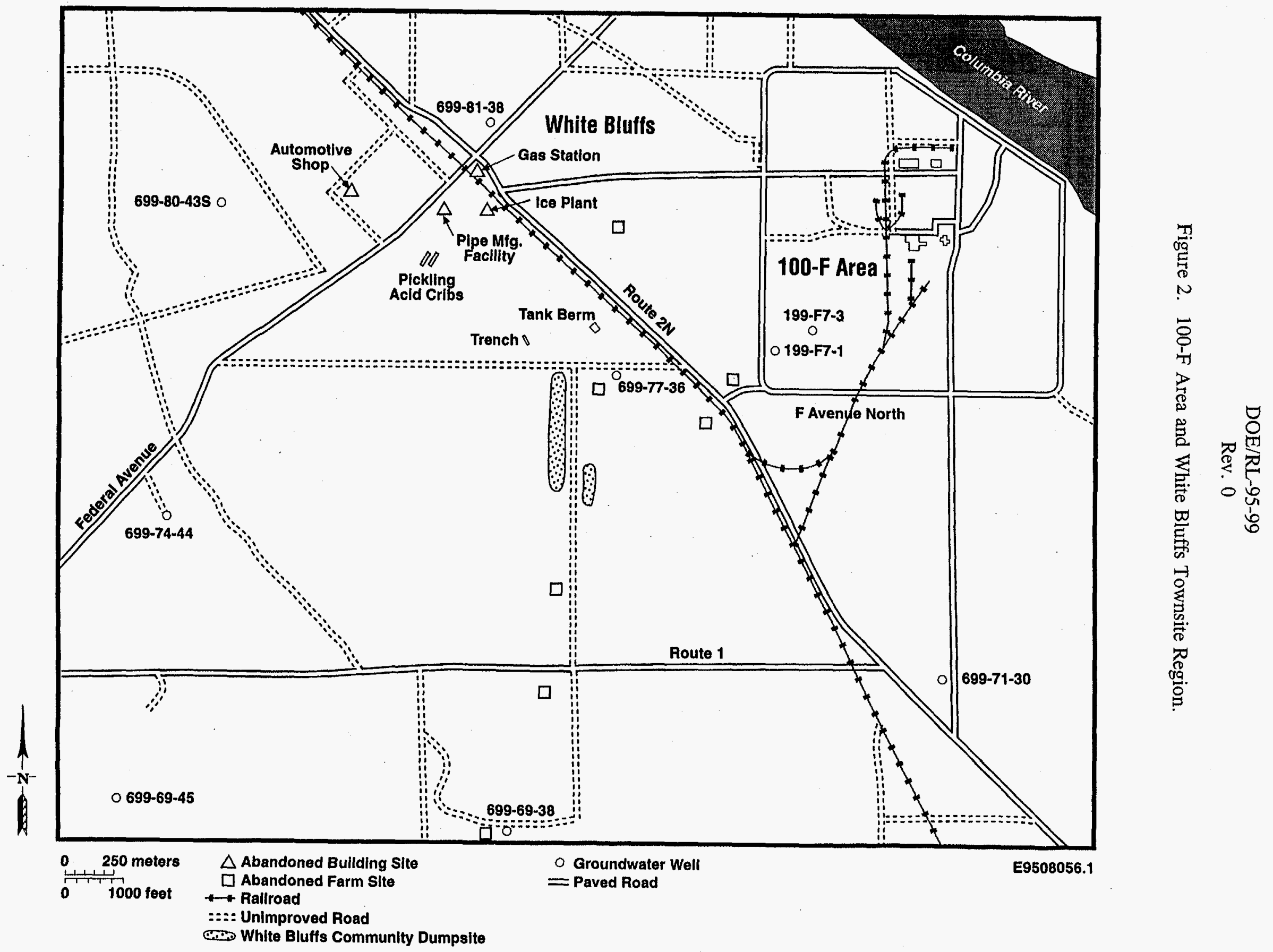


The contaminant of concern for this study was TCE. TCE is a volatile chlorinated hydrocarbon compound widely used as a metal degreasing agent in the United States from about the mid-1920's to the mid-1970's. The compound was also commonly used for dry cleaning purposes during this time period. During the mid-1970's, concern about the toxicity and environmental persistence of the compound led to its declined use. Because it is volatile, more dense than water, and somewhat soluble in water, TCE has a relatively high potential to contaminate groundwater.

TCE was primarily used on the Hanford Site as a degreasing agent. Also, the material was probably used in small amounts by the White Bluffs residents prior to Hanford operations. Several piles of discarded automotive wastes that predate Hanford were observed in the study area, particularly along the old road running south from White Bluffs. Unmarked 1-gal solvent cans were observed in some of the waste piles. This small-scale disposal was probably not sufficient to create significant groundwater contamination. There is no record or evidence of any dry cleaning facility at White Bluffs. There was, however, at least one service station that could represent a potential source of spent TCE. Several Hanford operations in the study area could also be potential sources of TCE contamination. A likely potential source is the former American Pipe manufacturing facility in the northwest portion of the study area. TCE was probably a principal metal degreasing agent used in the facility. Also, evidence of Hanford-related waste disposal (empty drums) was noted in two locations.

\subsection{INVESTIGATION STRATEGY}

During the LFI conducted in 1993, TCE was identified in well 199-F7-1 in the southwest corner of 100-F Area at a concentration of $28 \mu \mathrm{g} / \mathrm{L}$ (DOE-RL 1994). This level had increased from about $10 \mu \mathrm{g} / \mathrm{L}$ detected in 1987. Based on this finding, TCE was considered a COPC for the 100-FR-3 Operable Unit. Historical data showed that well 699-77-36, located about $1 / 2$ mile west of well 199-F7-1, also contained TCE at a range of 27 to $35 \mu \mathrm{g} / \mathrm{L}$ since 1987. Figure 3 shows the TCE concentrations detected in wells 199-F7-1 and 699-77-36. In addition, the LFI indicated several 100-F Area wells located northeast of well 199-F7-1 contained TCE in estimated concentrations ranging from 3 to $7 \mu \mathrm{g} / \mathrm{L}$.

The overall strategy and action levels of the investigation were developed during the project data quality objectives (DQO) process. The DQOs are included as an appendix to the project description of work (DOW) (BHI 1995a). The primary goal of the investigation was to determine the general distribution of TCE in the shallow groundwater throughout the study area while focusing on identifying any surface source of TCE that could be a source of the TCE found in wells 199-F7-1 and 699-77-36. Screening goals were established to see if a source of TCE could be located that might be attributed to a waste site. Three groundwater action levels were set to guide the investigation. The lower action level for the groundwater TCE concentration was set at $10 \mu \mathrm{g} / \mathrm{L}$. The primary objective of the study was to define regions where TCE concentrations exceed $10 \mu \mathrm{g} / \mathrm{L}$. An intermediate action level of $50 \mu \mathrm{g} / \mathrm{L}$ TCE was selected to indicate a region of groundwater contamination that represented a potential source of the TCE levels measured in groundwater wells 199-F7-1 and 699-77-36. An upper action level of $500 \mu \mathrm{g} / \mathrm{L}$ TCE was selected to indicate a region of significant groundwater contamination requiring investigation beyond the scope of this study. 
Figure 3. Plot of Historical Trichloroethylene Concentrations Detected in Wells 199-F7-1 and 699-77-36.

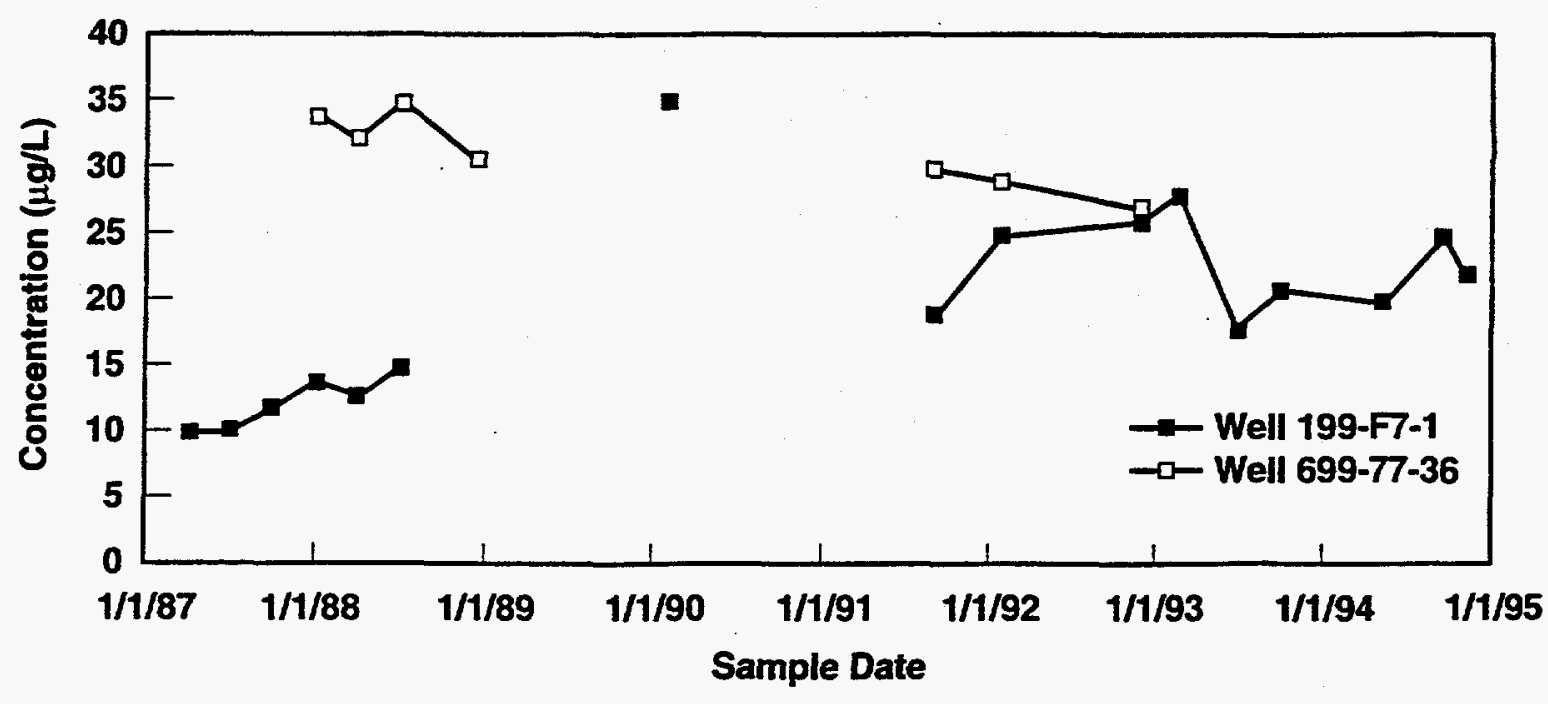

E9508056.3

Unbiased sampling was accomplished using a sampling grid set out on 1,200-ft centers. Soil gas and groundwater grab samples were collected at each grid point for field screening analysis. If the TCE groundwater concentration at any outside grid point exceeded $10 \mu \mathrm{g} / \mathrm{L}$, an additional sampling point was established 1,200 ft out from grid. These points were referred to as "step out" grid points. The soil gas and groundwater TCE concentrations were contoured and mapped to determine the extent of the contaminant plumes.

At each grid location where a groundwater sample was collected, the depth to groundwater was determined to the nearest $0.1 \mathrm{~m}$. These values were used with the surface elevation data to determine the groundwater elevation throughout the site. The groundwater elevation data were contoured and mapped to determine the direction of groundwater flow throughout the study area.

Finally, the soil gas TCE values were compared to the groundwater TCE values to determine if a positive correlation between soil gas and groundwater TCE concentrations could be established. If the soil gas/groundwater correlation was acceptable, the soil gas data could be used to map the underlying groundwater contamination and locate potential sources of TCE contamination in the vadose zone. A combination of additional soil gas samples and selected groundwater sampling was proposed in the DOW to further define regions where the groundwater TCE concentration exceeded $50 \mu \mathrm{g} / \mathrm{L}$.

Although the groundwater TCE concentration exceeded $50 \mu \mathrm{g} / \mathrm{L}$ at one sampling location, no additional characterization was conducted. Instead, the coarse grid was expanded south of the detected highconcentration area to determine if the plume had been identified and to attempt to locate a potential source. Once the plume had been delineated and no significant source could be identified, the project team (including representatives from the EPA and Ecology) determined the TCE levels had been adequately characterized and no additional sampling was necessary. This decision was documented in the project meeting minutes for July 13, 1995. 
DOE/RL-95-99

Rev. 0

\subsection{METHODS}

This investigation was conducted in accordance with the 100-FR-3 Groundwater/Soil Gas Supplemental Limited Field Investigation Description of Work (BHI 1995a). As the work proceeded, some of the procedures in the DOW were modified to improve the quality of the data collected. The following sections describe the specific methods, and modifications where needed, that were used to conduct the project.

\section{$5.1 \quad$ SAMPLING GRID}

The sampling grid was first drawn on a scale map of the study area with the distance between each sampling location set at $1,200 \mathrm{ft}$. In the field, the position of each sampling location was determined using a Brunton compass (registered trademark of Brunton USA) and a Rolatape survey wheel (a product of Rolatape Corporation, Spokane, Washington). The grid was established beginning at location 22, which is adjacent to well 699-77-36. The remainder of the sampling locations were positioned in the field relative to this location. Each sampling location was marked with a 4-ft wooden stake identified with the location number and flagging tape.

After the grid was established, the groundwater and soil gas probes were installed using a truckmounted hydraulic probe driver. In some cases the actual sampling location was moved as much as $200 \mathrm{ft}$ to facilitate installation of the probes or access to the sampling location. After the groundwater probe was installed, sampled, and removed, the location of the probe was marked with a 1-ft wooden stake driven adjacent to the sampling location. Each stake was marked with the sample location number and a horizontal line indicating the reference ground surface.

In accordance with the project DQOs, if the groundwater concentration on any outside grid location exceeded $10 \mu \mathrm{g} / \mathrm{L}$, an additional sampling location was set up 1,200 ft from the original location. These "step out" grid points expanded the sampling grid outward. Several "step out" grid points were used in the project. Also, in the final stage of the project, 11 additional grid locations were established in the southern portion of the study area to ensure the outer boundary of the plume had been determined. Figure 4 shows the original sampling grid and all of the "step out" sampling locations. The "step out" locations were established in the field from the original grid locations using the Brunton compass and the survey wheel.

Once the sampling was complete, each grid location was surveyed using Trimble 4000 SE Land Surveyor II Global Positioning System (GPS) equipment (registered trademark of Trimble Navigation, Ltd.) operated in kinematic mode. The horizontal position of each groundwater sampling location marked by the 1 - $\mathrm{ft}$ wooden stake was determined to an accuracy of $\pm 5 \mathrm{~cm}$ ( \pm 2 in.). The horizontal coordinates for each sampling location were determined in Washington State Plane south zone, NAD83, meters. In addition, the vertical elevation of each groundwater sampling location marked by the 1 - $\mathrm{ft}$ wooden stake was determined to an accuracy of $\pm 10 \mathrm{~cm}( \pm 4 \mathrm{in}$.). The vertical elevations are based on the NAVD88 datum. 


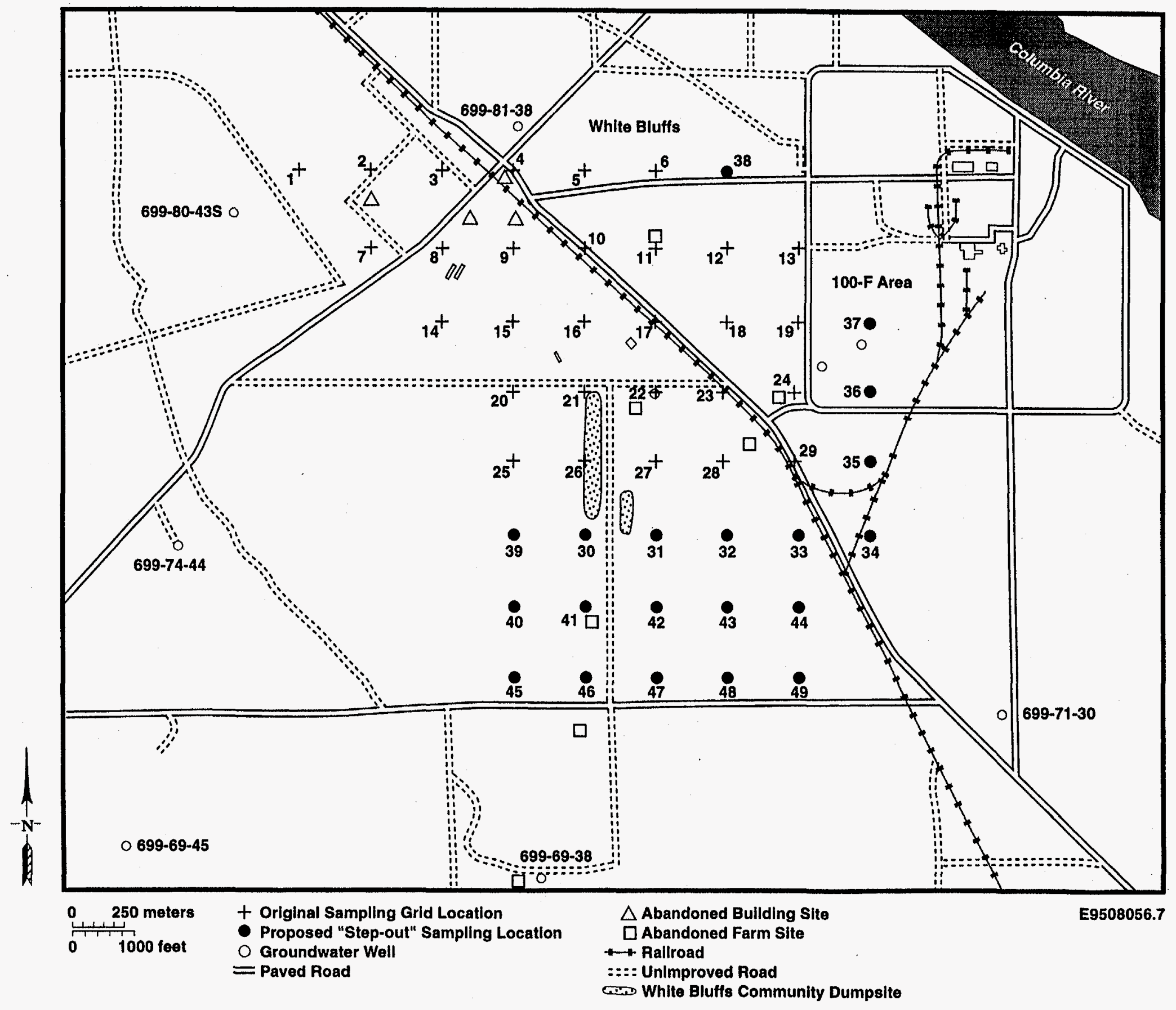




\subsection{SOIL GAS SAMPLES}

A 1-in.-outer diameter (OD) sampling probe was driven into the ground at each sampling location using a Model 5400 hydraulic probe driver (registered trademark of Geoprobe Systems). The probes were installed in accordance with Environmental Investigations Procedure (EIP) 5.1, "Soil-Gas Sampling" (BHI 1994b). Each sampling probe consisted of 3- or 4-ft probe rod sections screwed end to end as the sampling probe was driven to the desired depth. The desired sampling depth corresponded to approximately 3 to $5 \mathrm{ft}$ above the anticipated level of groundwater. In many locations this depth was difficult to estimate. The probes were often driven to a depth of about 15 to $20 \mathrm{ft}$ below ground surface (bgs). In some cases the probe was driven below the water table. When groundwater was detected in the soil gas sampling train, the probe was backpulled until it was estimated to be about 3 to $5 \mathrm{ft}$ above the water table.

Once the sampling probe was driven to the desired depth, the probe was pulled back about 3 to 4 in. to disengage the probe drive tip from the probe rod. This also created a void space in the soil column to collect a soil gas sample without plugging the end of the probe rod. The probe depth and sampling depth were determined by subtracting the amount of probe rod stickup from the total length of probe rod driven and were recorded in the field logbook. In addition, comments concerning the relative resistance encountered when driving the probe rod into the ground were recorded in the field logbook as each probe was installed.

After the probe rod was in position, a 25 - to 30 -ft length of $1 / 4$-in.-OD polyethylene (PE) tubing attached to a threaded stainless-steel adapter was inserted down to the bottom of the probe rod. The insert adapter was screwed into the prethreaded tip holder at the end of the probe rod. A rubber O-ring on the stainless-steel adapter was used to ensure the sample tubing was sealed at the end of the probe rod. The PE tubing was then attached to a vacuum pump using a 3-in. section of silicon tubing. The vacuum pump was used to withdraw $1 \mathrm{~L}$ of soil gas through the PE tubing. This purge volume was predetermined to represent at least three tube volumes. The volume of the PE tubing is about $10 \mathrm{~mL} / \mathrm{ft}$.

After the sample tubing was purged, a $500-\mu \mathrm{L}$ soil gas sample was collected using a $1.0-\mathrm{mL}$ air-tight glass syringe. The sample was taken by inserting the syringe needle through the section of silicon rubber tubing connecting the PE tubing to the vacuum pump system. After the sample was collected, the syringe needle was inserted into a rubber septum to prevent loss of the sample while it was transported to a mobile laboratory for analysis. At the laboratory, sample location, depth, date, time, and a unique Hanford Environmental Information System (HEIS) sample number were recorded on the laboratory sample custody/log sheet.

Each sample was analyzed for TCE concentration using a Photovac 10S Plus (registered trademark of Photovac International, Inc.) portable gas chromatograph (GC) (10S Plus). The 10S Plus was operated in accordance with Field Screening Procedure (FSP) 1.6, "Analysis of Volatile Organic Compounds in Soil Gas" (BHI 1995b). The 10S Plus is a self-contained, battery-powered portable GC that uses a $10-\mathrm{m}$, nonpolar, wide-bore, capillary column and a photoionization detector with a 10.6-eV lamp. The $500-\mu \mathrm{L}$ soil gas samples were injected directly to the column. The $10 \mathrm{~S}$ Plus was operated isothermally at $40^{\circ} \mathrm{C}$ using ultra high-purity air carrier gas at a flow rate of $5 \mathrm{~mL} / \mathrm{min}$.

The 10 S Plus was equipped with a library to detect a variety of compounds based on retention time. Identified compounds were quantified based on peak area, with appropriate response factors for each compound of interest. Three-point calibration curves for cis-1,2-dichloroethylene (cis-1,2-DCE), TCE, 
tetrachloroethylene (PCE), and toluene were developed using calibration gas standards. The calibration gas standards have a concentration tolerance of $\pm 2 \%$.

At the beginning of each sampling day, the $10 \mathrm{~S}$ Plus calibrations were updated using a gas calibration standard containing about 1 part-per-million-volume/volume (ppm-v) of cis-1,2-DCE, TCE, and PCE. An ambient air/equipment blank sample was collected each sampling day and analyzed to establish the instrument baseline response and ensure the sampling train was not contaminated. One duplicate gas sample was also collected and analyzed each sampling day. At the end of the sampling day, the calibration gas standard was analyzed as a sample to determine the calibration drift and ensure the quality of the data. Operation and calibration of the $10 \mathrm{~S}$ Plus was documented in the instrument logbook. The calibration drift data were tracked using an instrument control chart to verify the instrument was operating within acceptable control limits.

\subsection{GROUNDWATER SAMPLES}

After the soil gas sample was collected, the probe rod was withdrawn using the Geoprobe 5400 hydraulic probe. A groundwater sampling probe was then installed in the hole created by the soil gas probe. The groundwater sampling probe consisted of 3- or 4-ft probe rod sections used to collect the soil gas samples. Later in the investigation, a 3- or 4- $\mathrm{ft}$ section of perforated probe rod (slots or small holes) was added to the end of the sampling rod to facilitate recharge of groundwater into the probe. The groundwater sampling probe was driven to a depth corresponding to about 3 to $5 \mathrm{ft}$ below the water table in the same manner as the soil gas probe using 3- or 4-ft probe rod sections screwed end to end as the probe was driven into the ground.

The probe depth and sampling depth were determined by subtracting the amount of probe rod stickup from the total length of probe rod driven and recorded in the field logbook. The depth to the groundwater surface was determined using a Solinst electric tape (e-tape) (a product of Glen Williams, Ontario, Canada). The e-tape had been standardized on July 30, 1994 and checked for deviation on January 30,1995 . The depth to groundwater below ground surface was determined by subtracting the measured amount of probe stickup from the depth to the water table measured using the e-tape and recorded in the field logbook. In addition, comments concerning the relative resistance encountered when driving the probe rod into the ground were recorded in the field logbook as the probes were installed.

After the depth to groundwater was determined, a groundwater grab sample was collected. The groundwater samples were collected using a length of new, 3/8-in. PE tubing with a stainless-steel check valve assembly attached to the sampling end. The tubing was pushed down the probe into the groundwater and pumped up and down several times to draw water up into the tubing. For samples deeper than 15 to $20 \mathrm{ft}$, the tubing was also attached to the vacuum pump assembly and a vacuum was used to help draw groundwater into the tube. Once the tubing contained an adequate volume of water, the tubing was quickly pulled up out of the probe. The first sample collected was discarded in the waste water container as purge water. The check valve was then cleaned and reinstalled on the PE tubing, and a second groundwater grab sample was collected in the same manner. At least one 30-mL water sample was collected in a $40-\mathrm{mL}$ volatile organic analysis vial. In many cases duplicate samples were collected. After the sample was collected, it was transported to a mobile laboratory for analysis. At the laboratory, sample location, depth, date, time, and a unique HEIS sample number were recorded in the laboratory sample custody/log sheet. 
In addition, 40-mL samples of groundwater were collected from seven groundwater monitoring wells in the region. The samples were collected by Environmental Restoration Contractor sampling technicians following standard sampling procedures. The samples were preserved and held for analysis at the mobile laboratory.

Each sample was analyzed for TCE concentration using the 10S Plus portable GC. The 10 S Plus was operated in accordance with FSP 1.1, "Aqueous Headspace Analysis of Volatile Organic Compounds in Water" (BHI 1995b). A $250-\mu \mathrm{L}$ aliquot of the headspace above each water sample was collected using a clean, glass, air-tight syringe and injected directly to the column. The 10 S Plus was operated in the same configuration as described for the soil gas samples.

The $10 \mathrm{~S}$ Plus was equipped with a library to detect a variety of compounds based on retention time. Identified compounds were quantified using peak area, with appropriate response factors for each compound of interest. Three-point calibration curves for cis-1,2-DCE, TCE, PCE, and toluene were developed using aqueous standards.

At the beginning of each sampling day, the $10 \mathrm{~S}$ Plus calibrations were updated using a prepared liquid standard containing about $50 \mathrm{ppb}(\mu \mathrm{g} / \mathrm{L})$ each of TCE and PCE. Headspace from a sample of clean, deionized water was analyzed after the calibration as a blank to establish the instrument baseline response and ensure the sampling equipment was not contaminated. At least one duplicate water sample was collected and analyzed each sampling day. At the end of the sampling day, the calibration water standard was analyzed as a sample to determine the calibration drift and ensure the quality of the data. Operation and calibration of the $10 \mathrm{~S}$ Plus was recorded in the instrument logbook. The calibration drift data were tracked using an instrument control chart to verify the instrument was operating within acceptable control limits.

After the groundwater samples had been collected, the groundwater probe was left in the ground 1 to 2 hours to allow the groundwater to recharge within the probe. The depth to groundwater was then remeasured to verify the original depth measurement and to ensure the sampling probe could adequately recharge. The depth to groundwater below ground surface was recorded in the field logbook. The probe was then withdrawn using the Geoprobe 5400. All rod sections contaminated with groundwater were triple rinsed in the field using deionized water and allowed to air dry before they were used again. In addition, any reusable sampling equipment contacting groundwater was decontaminated and allowed to air dry before reuse. The waste decontamination water, contaminated $\mathrm{PE}$ tubing, and other disposable sampling equipment were collected in the field and periodically transported to the Environmental Analytical Laboratory (EAL) where they were staged for final disposal in accordance with standard operating procedures.

At one sampling location, location 32, groundwater samples were collected from two different depths to determine a depth profile of TCE concentration in the underlying groundwater. After the first groundwater sample was collected, the groundwater probe was pushed an additional 2 to $3 \mathrm{~m}$. The groundwater was then purged from the probe and allowed to recharge. Once the groundwater probe had recharged, a groundwater sample was collected from the bottom portion of the probe. The probe rod was then backpulled. 


\subsection{QUALITY ASSURANCE/QUALITY CONTROL SAMPLES}

A minimum of one duplicate soil gas sample and one duplicate groundwater sample were collected each sampling day. The duplicate soil gas samples were analyzed using the portable 10S Plus GC in the same manner described for the routine soil gas samples. About $30 \%$ of the duplicate groundwater samples collected were transported to the EAL for analysis. The EAL is a quick-turnaround environmental laboratory located about 5 miles from the 100-FR-3 site. At the EAL, the groundwater samples were analyzed for volatile organic compounds (VOC) by purge and trap using a Hewlett-Packard 5890 GC equipped with a Hewlett-Packard 5972 Mass Spectrometer Detector. The analyses were conducted in accordance with EAL Operations Procedure LA-523-511, "Analyses of Volatile Organics in Soil and Water by Purge and Trap" (BHI 1994a). The procedure is equivalent to SW-846 Method 8260 and uses the National Bureau of Standards 75,000 compound library (NBS75K) for positive compound identification along with a five-point calibration curve for quantification.

During the early stages of the project, the majority of the duplicate or replicate groundwater samples were analyzed at the EAL to confirm the accuracy of the portable GC results. Once the portable GC results were satisfactorily confirmed, most of the duplicate groundwater samples were analyzed using the portable GC in the same manner described for the routine samples. The duplicate samples were collected and analyzed in order to assess the precision of the analytical techniques.

Replicate soil gas and groundwater grab samples were collected at six randomly selected grid locations. Replicate samples were collected using a separate set of soil gas and groundwater probes installed $3 \mathrm{ft}$ in a designated direction from the original sampling location. Replicate soil gas and groundwater grab samples were collected from the probes following the methods described earlier and analyzed in the same manner previously described. The replicate samples were collected in order to assess the precision of the sampling technique.

\subsection{RESULTS AND OBSERVATIONS}

\subsection{SOIL GAS RESULTS}

Table A-1 shows soil gas VOC concentrations in parts-per-billion-volume/volume (ppb-v) for each of the grid and "step out" locations sampled. The principal analyte detected was TCE; however, trace amounts of toluene were detected in some locations and are shown in the table. The table also shows each sample HEIS number and the sampling depth in meters. The TCE values range from less than the detection level $(2.0 \mathrm{ppb}-\mathrm{v})$ to a high value of $77 \mathrm{ppb}-\mathrm{v}$.

During the early portion of the study, it was difficult to accurately determine the depth to groundwater through the sampling rod. The open end of the sampling rod apparently was not of sufficient diameter to allow the groundwater to equilibrate within the rod. As a result, some of the soil gas samples were inadvertently collected below the water table and not in the vadose zone. These unrepresentative samples became evident when more accurate depths to groundwater were determined for the sample location and by the relatively low TCE concentrations in the samples. Since these sample results were not representative of vadose zone concentrations, they were eliminated from the data set and are not included in Table A-1. When this problem was identified, a perforated sampling rod was installed at the end of the sampling rod. This configuration was much more effective for determining the depth to 
groundwater. Accurate depth-to-groundwater measurements ensured that the soil gas samples were collected from a uniform depth of about 3 to $5 \mathrm{ft}$ above the water table.

Figure 5 is a map of soil gas TCE concentrations detected in the study area. The contour lines indicate regions of TCE concentrations in parts-per-billion-volume/volume. The data were contoured using Surfer for Windows, a contouring and three-dimensional surface software package (a trademark of Golden Software, Inc.). The contours were produced using the linear Kriging algorithm supplied with the software. The actual soil gas sampling positions are also shown in Figure 5. The figure shows two regions of elevated soil gas TCE levels, one near the center and one near the south corner of the study area. The regions of elevated soil gas TCE concentrations did not show any direct correlation to any observed or anticipated source of TCE contamination.

\subsection{GROUNDWATER RESULTS}

Table A-2 shows the groundwater elevation for each of the grid and "step out" sampling locations in meters. The table lists the horizontal coordinates and vertical elevations determined by the GPS in meters. The table also shows the coordinates and elevations for each of the groundwater wells sampled in the study area. The groundwater elevation values were determined by subtracting the measured depth to groundwater at each sampling location from the surface elevation value determined by the GPS. The values were rounded to the nearest tenth of a meter.

Figure 6 is a map of the groundwater elevations measured in the study area. Each contour line represents $0.5-\mathrm{m}$ increments of groundwater elevation. The contours were derived using Surfer for Windows in the same manner as described in the Section 6.1. The actual position of each groundwater sampling location is also shown in Figure 6. The general contour trend was determined using the groundwater elevation values obtained from the groundwater monitoring wells shown in Figure 6. Selected groundwater elevation values obtained through the groundwater sampling probes were also used to add further detail to the map. As was previously mentioned, groundwater depth values collected early in the study were not accurate and many were not used to contour the data. No groundwater samples were collected near the Columbia River. Mapping the groundwater conditions influenced by the river was not within the scope of the supplemental LFI. Depths to groundwater near the Columbia River are estimated and are not meant to represent actual conditions in this region.

The groundwater contours indicate the general movement of groundwater in the study area is to the northeast. Highest groundwater elevations appear to be near the northern flank of Gable Mountain (located south of the study area). This region of Gable Mountain may represent a source of local recharge to the regional unconfined aquifer and appears to influence the groundwater movement in the immediate area. As the groundwater approaches the northeastern portion of the study area, the effect of the Columbia River appears to result in a more easterly direction of groundwater movement. This general trend corresponds with the groundwater movement documented for this region in annual groundwater reports (PNL 1994). 
DOE/RL-95-99

Rev. 0

Figure 5. Soil Gas Trichloroethylene Concentrations in the 100-F Area/White Bluffs Townsite Region.

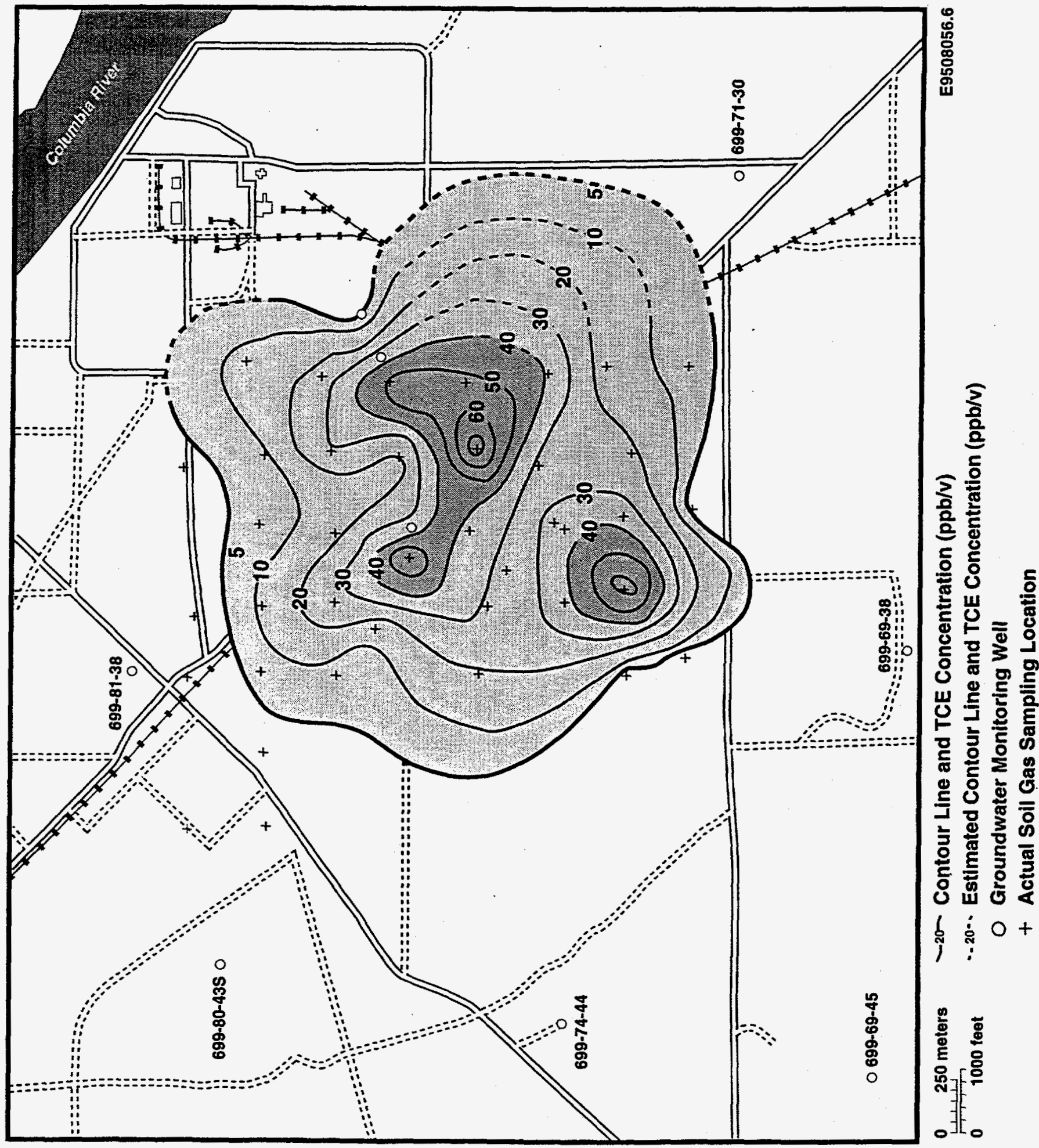




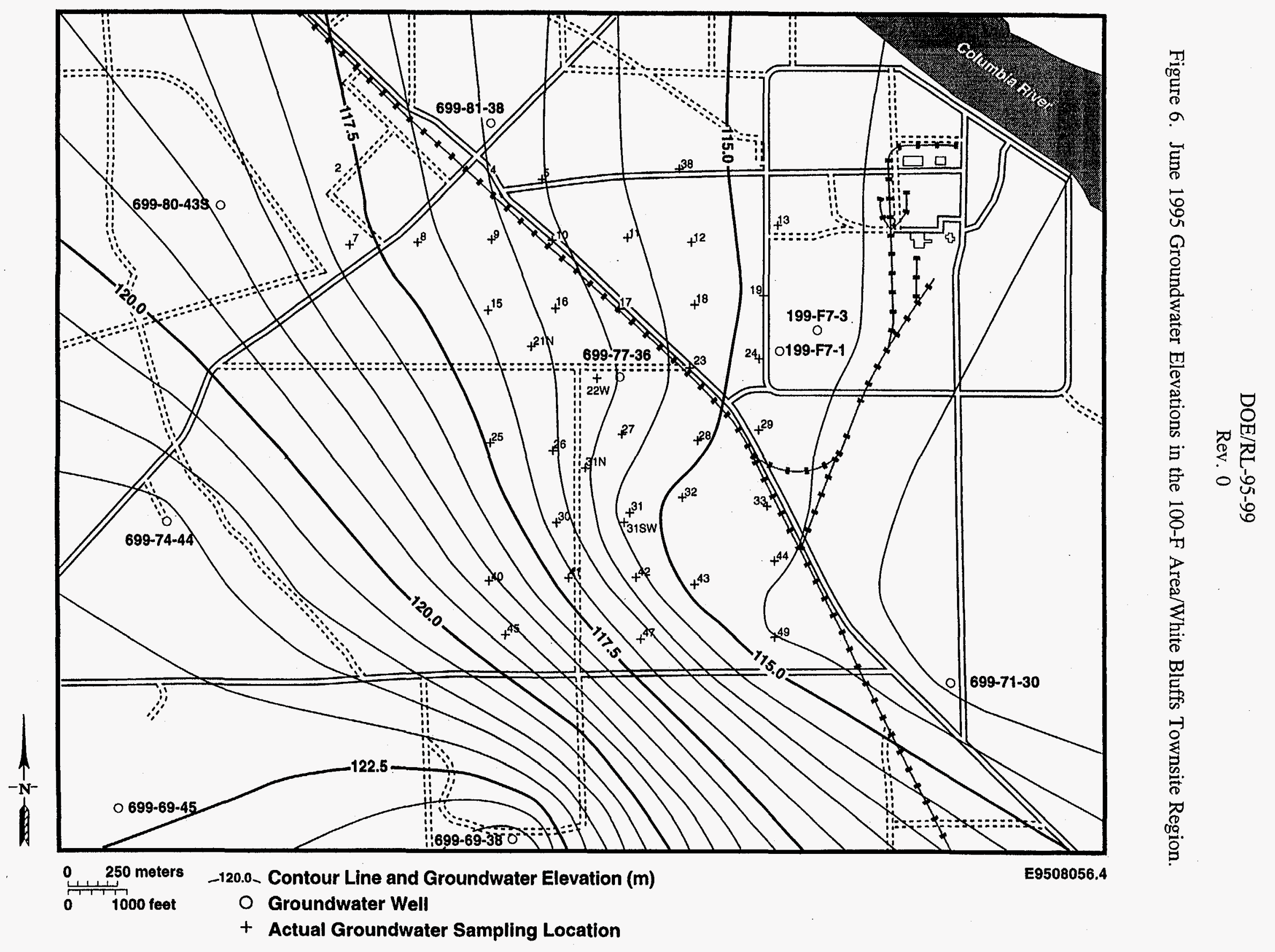


Table A-3 shows groundwater VOC concentrations in parts-per-billion $(\mu \mathrm{g} / \mathrm{L})$ for each of the grid and "step out" locations sampled. The principal analyte detected was TCE. As was observed in the soil gas samples, trace amounts of toluene were detected at some locations and are shown in the table. The table also shows each sample HEIS number and the sampling depth in meters. The TCE values range from less than the detection level $(0.5 \mu \mathrm{g} / \mathrm{L})$ to a high value of $52 \mu \mathrm{g} / \mathrm{L}$. The table also shows the TCE concentration detected in groundwater samples collected from seven groundwater wells in the study area.

Figure 7 is a map of groundwater TCE concentrations in the study area. The concentrations are shown in micrograms per liter $(\mu \mathrm{g} / \mathrm{L})$. The data were contoured using Surfer for Windows in the same manner as the soil gas data. The actual groundwater sampling positions are also shown in Figure 7 . The figure shows two regions of elevated groundwater TCE concentrations. The highest concentrations were detected at sampling location 31 , which is in a depression south of the White Bluffs community dump area. A group of several empty drums was observed in this dump site near location 31 . The second region of elevated groundwater TCE values was located to the northeast, near sampling locations 19 and 24. This region did not show any direct correlation to any observed or anticipated source of TCE contamination. In addition, low concentrations of TCE were detected in groundwater from the region near the pipe manufacturing facility and its associated waste sites. These low values may represent residual levels of the TCE disposed from these facilities.

At grid location 32, groundwater samples were collected from two different depths. A shallow groundwater sample was collected at a depth of $8.8 \mathrm{~m}$ bgs, which was about $1 \mathrm{~m}$ below the water table. The TCE concentration in the shallow sample was $23 \mu \mathrm{g} / \mathrm{L}$. A second sample was collected using the same sampling apparatus driven to a depth of $11.3 \mathrm{~m}$ bgs. This depth corresponded to about $3.5 \mathrm{~m}$ below the water table. The TCE concentration in the deeper sample was $26 \mu \mathrm{g} / \mathrm{L}$. This was the only location were an attempt to collect groundwater samples from different depths was successful. There is not sufficient information to suggest a trend in the data.

Figure 8 shows a plot of the correlation of soil gas TCE concentrations (ppb-v) to groundwater TCE concentrations $(\mu \mathrm{g} / \mathrm{L})$ from each sample point where representative samples were collected from both media. The line through the plot represents a one-to-one positive correlation of the soil gas to groundwater values. As can be observed by the distribution of the actual measured data points around the line, the data show poor positive correlation. At the $95 \%$ confidence level, the coefficient of correlation is 0.50 . This value is equivalent to a random distribution and indicates no direct correlation between the soil gas and groundwater TCE concentrations.

Figure 9 shows a map of the regions of groundwater TCE values greater than $20 \mu \mathrm{g} / \mathrm{L}$ superimposed over the regions of soil gas TCE values greater than $40 \mathrm{ppb}-\mathrm{v}$. The outer lines and shaded areas represent the lateral extent of the two plumes above $5 \mu \mathrm{g} / \mathrm{L}$ for groundwater and $5 \mathrm{ppb}-\mathrm{v}$ for soil gas. As can be observed, the general location and lateral extent of the two plumes correspond quite well. This appears to indicate a direct relationship between TCE detected in the vadose zone and TCE detected in the groundwater. The figure also shows that the regions of relatively higher groundwater TCE values are located adjacent to and northeast of the regions of relatively higher soil gas TCE values. This lateral displacement is in the same direction as the general movement of groundwater through the region. This trend may indicate that low levels of TCE are dissolved into the groundwater as it moves through a region containing $\mathrm{TCE}$ in the vadose zone. 
Figure 7. Groundwater Trichloroethylene Concentrations in the 100-F Area/White Bluffs Townsite Region.

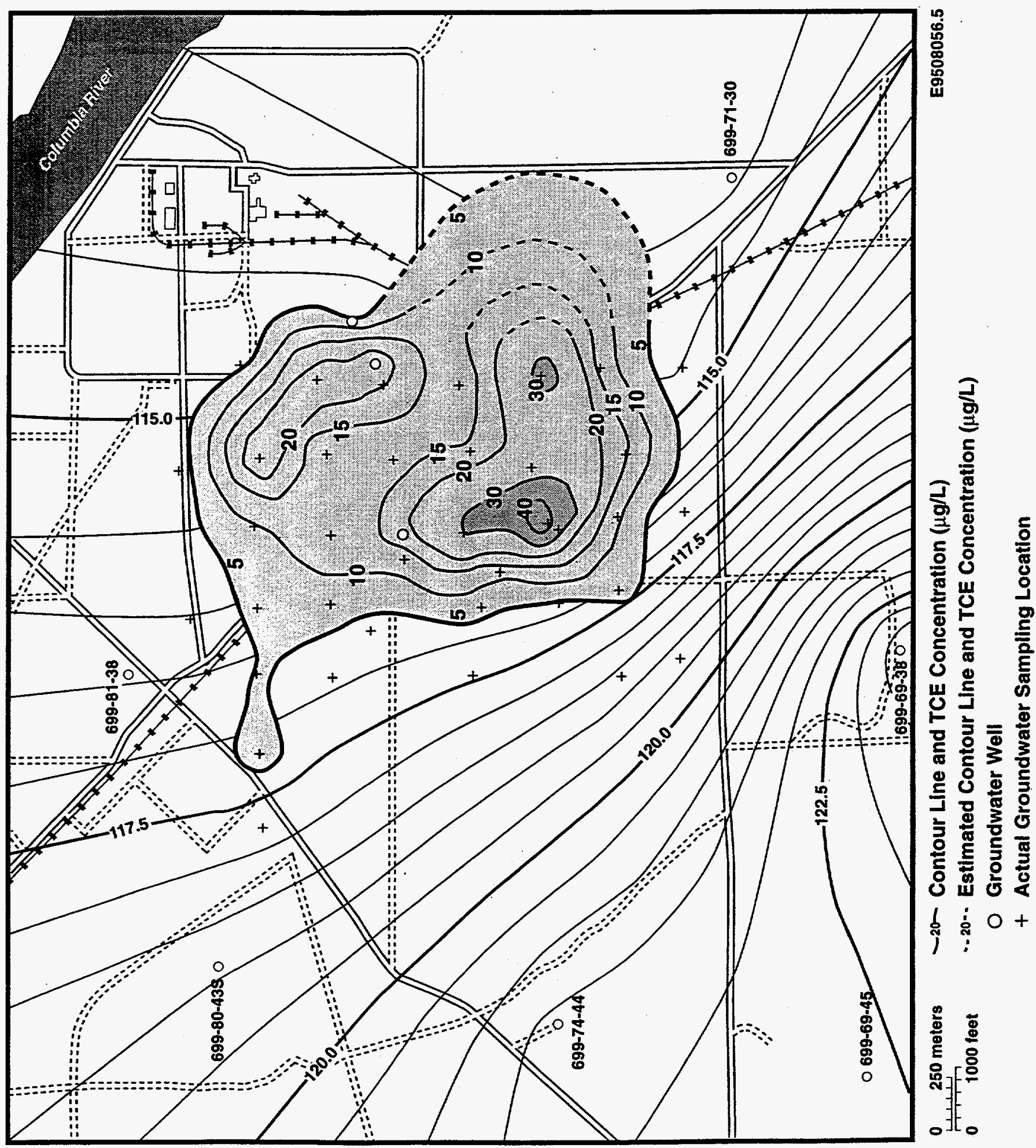


Figure 8. Plot of Soil Gas and Groundwater Trichloroethylene Concentrations.

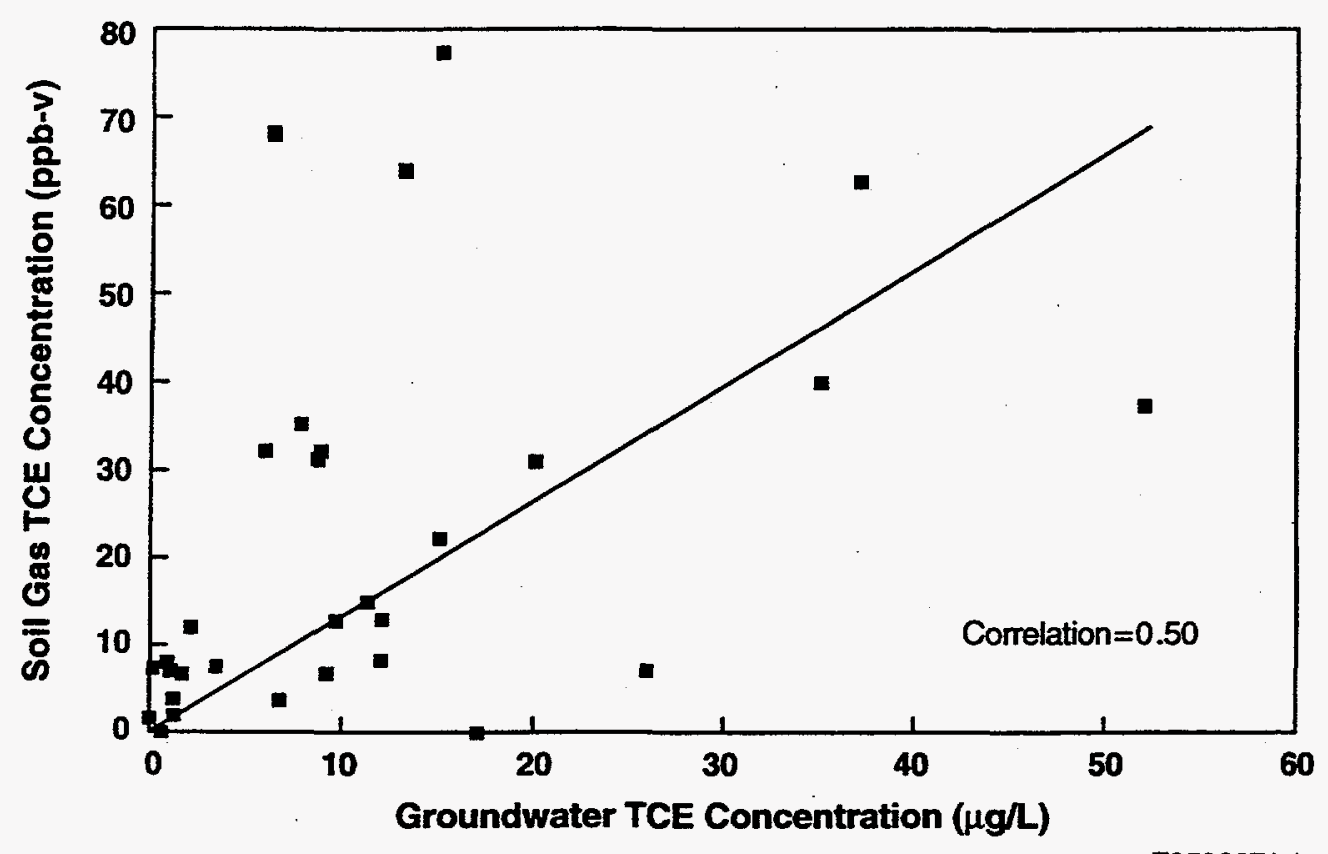

E9508071.1

Figure 10 shows a second plot of the correlation of soil gas to groundwater TCE concentrations. In this plot the soil gas TCE values have been shifted to correspond with the groundwater TCE values one grid location to the northeast. This shift was done to test the hypothesis that the groundwater contamination may be the result of TCE dissolving in the groundwater as it flows through a region of vadose zone contamination. The line through the plot represents a one-to-one positive correlation of the soil gas to groundwater values. This reduced data set shows a correlation of 0.71 at the $95 \%$ confidence level. This higher positive correlation appears to support the hypothesis.

\subsection{QUALITY ASSURANCE/QUALITY CONTROL RESULTS}

Table A-4 contains the results of duplicate and replicate soil gas samples collected during the investigation. The samples are listed by sample grid location. As was discussed in the previous section, some of the soil gas samples were inadvertently collected below the water table. These values, which included several of the sets of duplicate and replicate values were not representative of the vadose zone concentrations and were eliminated from the data set. Figures 11 and 12 show the correlation of the duplicate and replicate sample TCE results to the primary soil gas sample TCE results. In each of the plots, the line represents a one-to-one positive correlation of the duplicate or replicate values to the primary sample value. Although the number of data points is small, both the duplicate and replicate data show a strong positive correlation to the primary sample results. At the $95 \%$ confidence level, the duplicate samples show a correlation of 0.95 while the replicate samples show a correlation of 0.98 . 


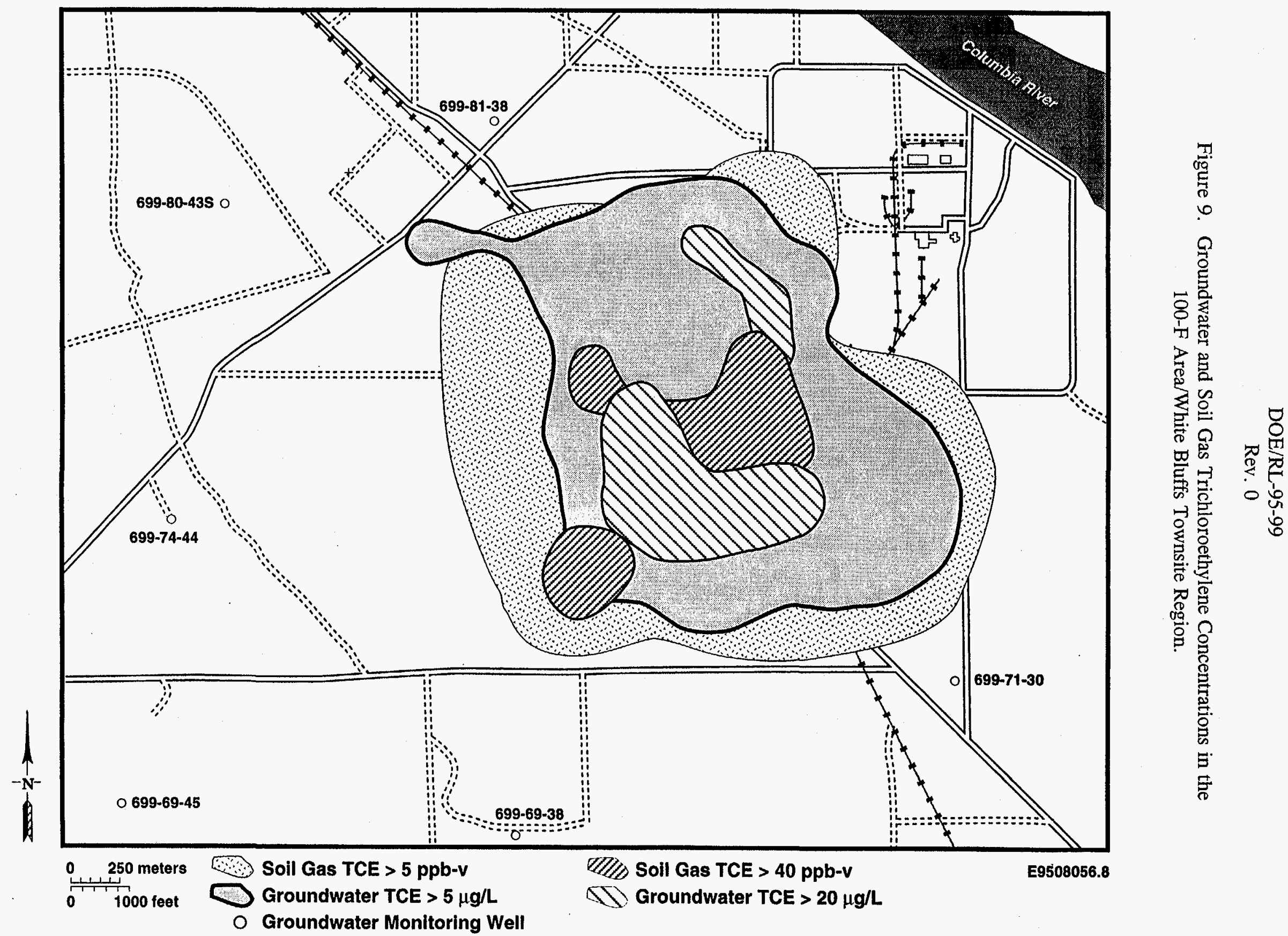


Figure 10. Plot of Shifted Soil Gas and Groundwater Trichloroethylene Concentrations.

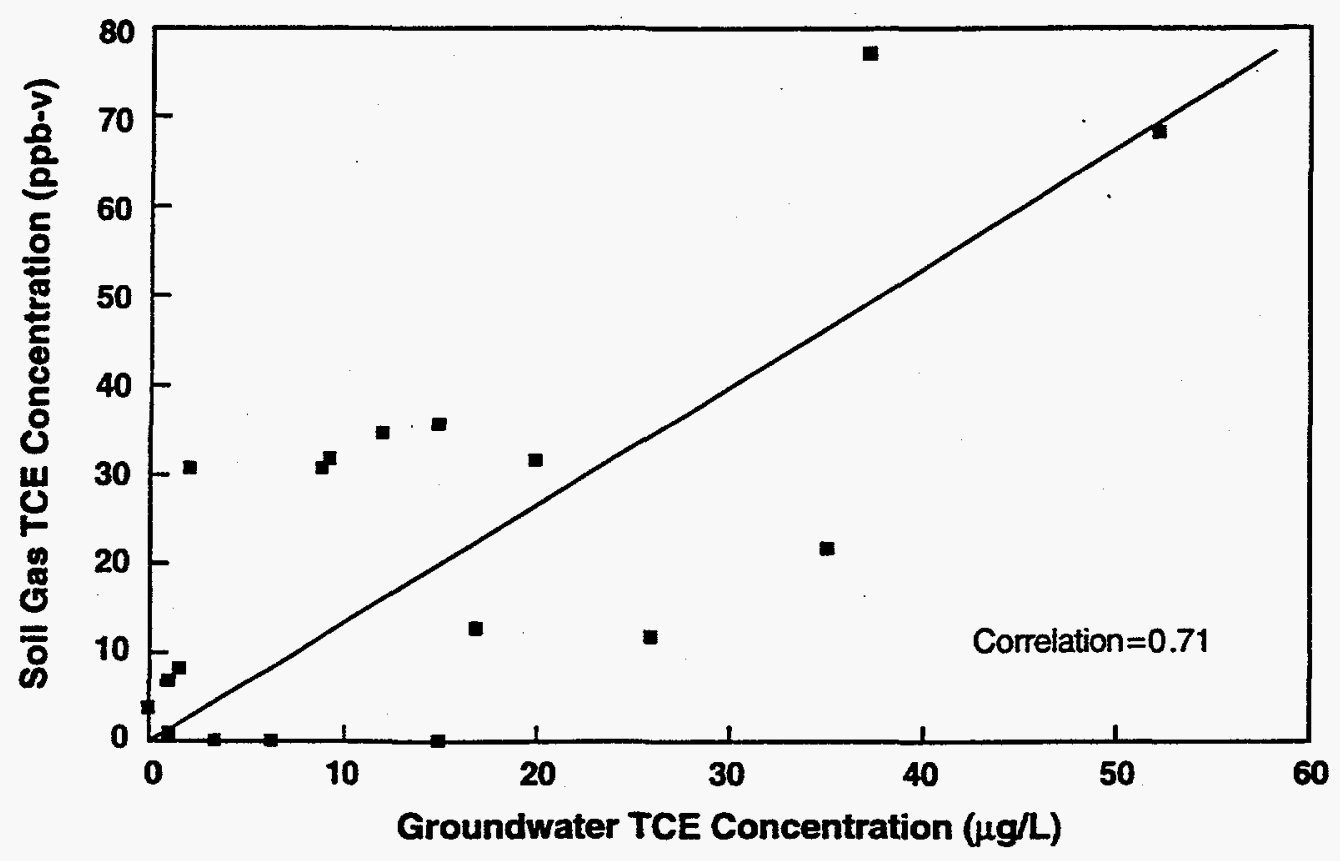

E9509065.1

Table A-5 contains the results of replicate groundwater elevation measurements collected during the investigation. The measurements are listed by sample grid location. As was discussed in Section 6.2, difficulties with the original sampling apparatus caused inaccurate depth to groundwater measurements. This problem is shown by the poor correlation of the replicate data for grid locations 7 and 9 .

Figure 13 shows the correlation of the replicate groundwater elevation measurements to the primary elevation measurements. The two data points on the lower right of the plot show the poor precision of the measurements collected at grid locations 7 and 9 . In the plot, the line represents a one-to-one positive correlation of the replicate measurements to the primary measurements excluding the measurements from grid locations 7 and 9 . At the $95 \%$ confidence level, the replicate measurements show a correlation of 0.90 . This positive correlation confirms the effect of the modified sampling equipment on the accuracy of the measurements.

Table A- 6 contains the results of duplicate and replicate groundwater samples collected during the investigation. The samples are listed by sample grid location. Figures 14 and 15 show the correlation of the duplicate and replicate sample results to the primary groundwater sample results. In each of the plots, the line represents a one-to-one positive correlation of the duplicate or replicate values to the primary sample value. The duplicate data show a strong positive correlation to the primary sample results. At the $95 \%$ confidence level, the duplicate samples show a correlation of 0.95 . The replicate data show a correlation of 0.70 at the $95 \%$ confidence level. However, the lower correlation indicates that the sampling method was somewhat ineffective in producing repeatable results. This result is related in part to the expected random nature of the TCE levels in the groundwater as well as the precision of the sampling technique. 
Rev. 0

Figure 11. Plot of Duplicate Soil Gas Sample Trichloroethylene Concentrations.

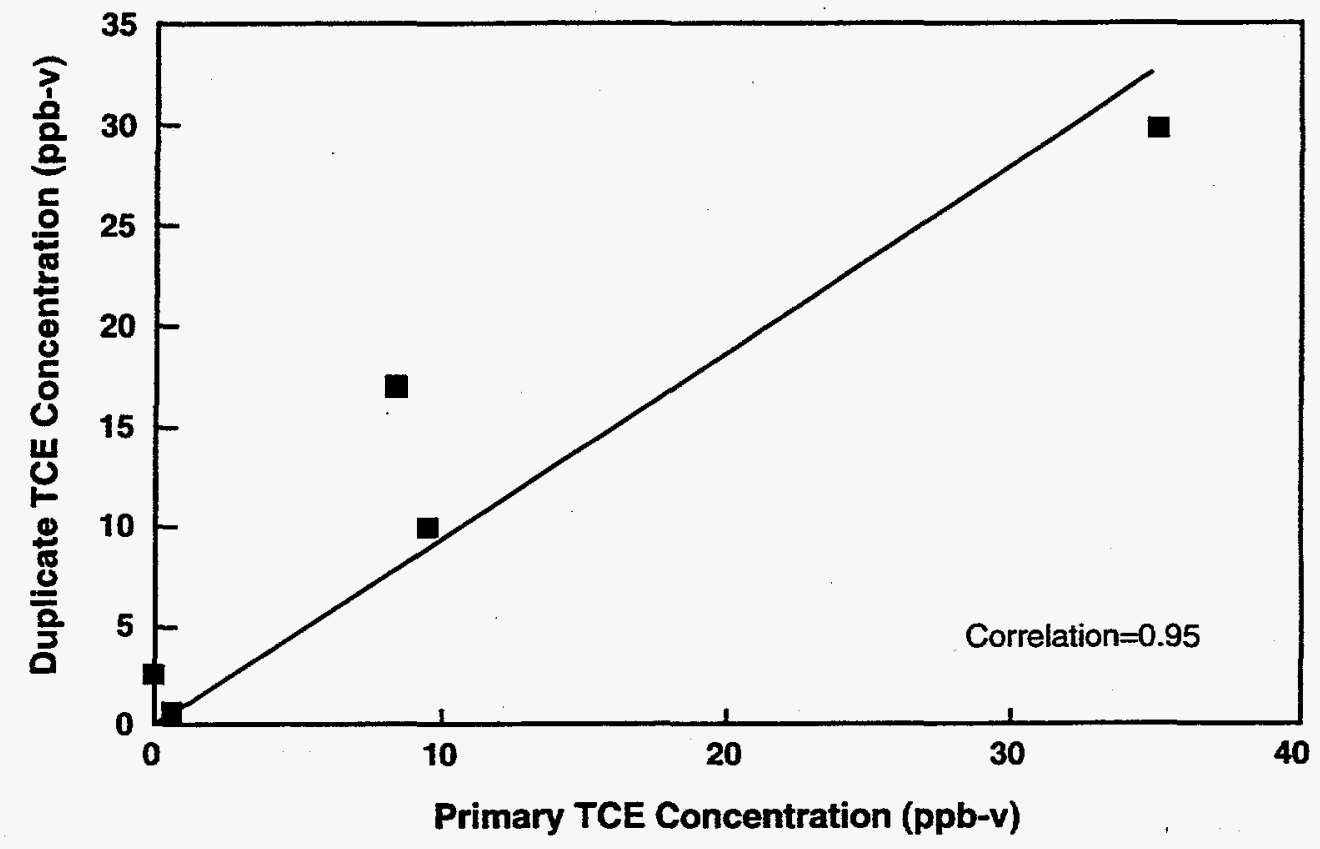

E9508071.5

Figure 12. Plot of Replicate Soil Gas Sample Trichloroethylene Concentrations.

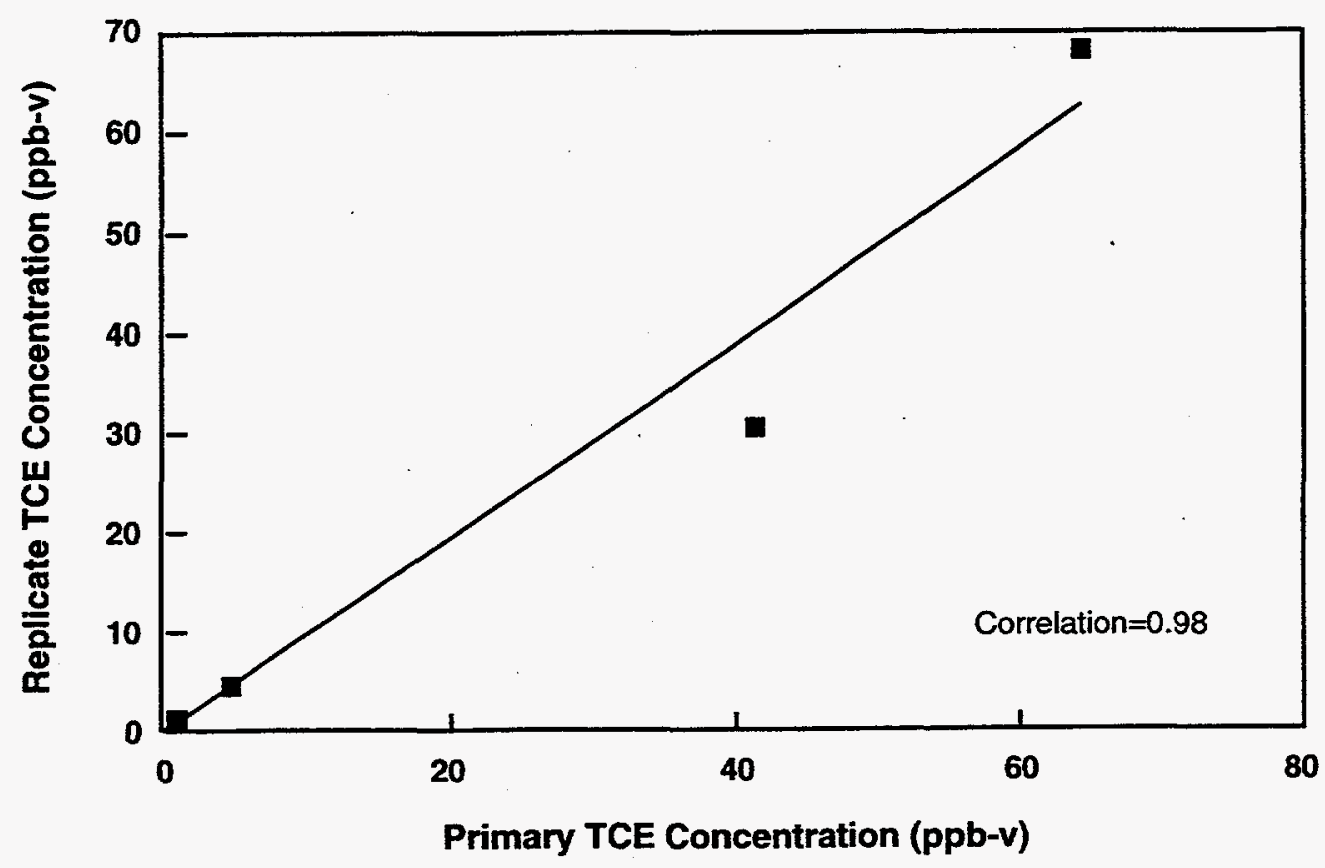


Rev. 0

Figure 13. Plot of Replicate Groundwater Elevation Measurements.

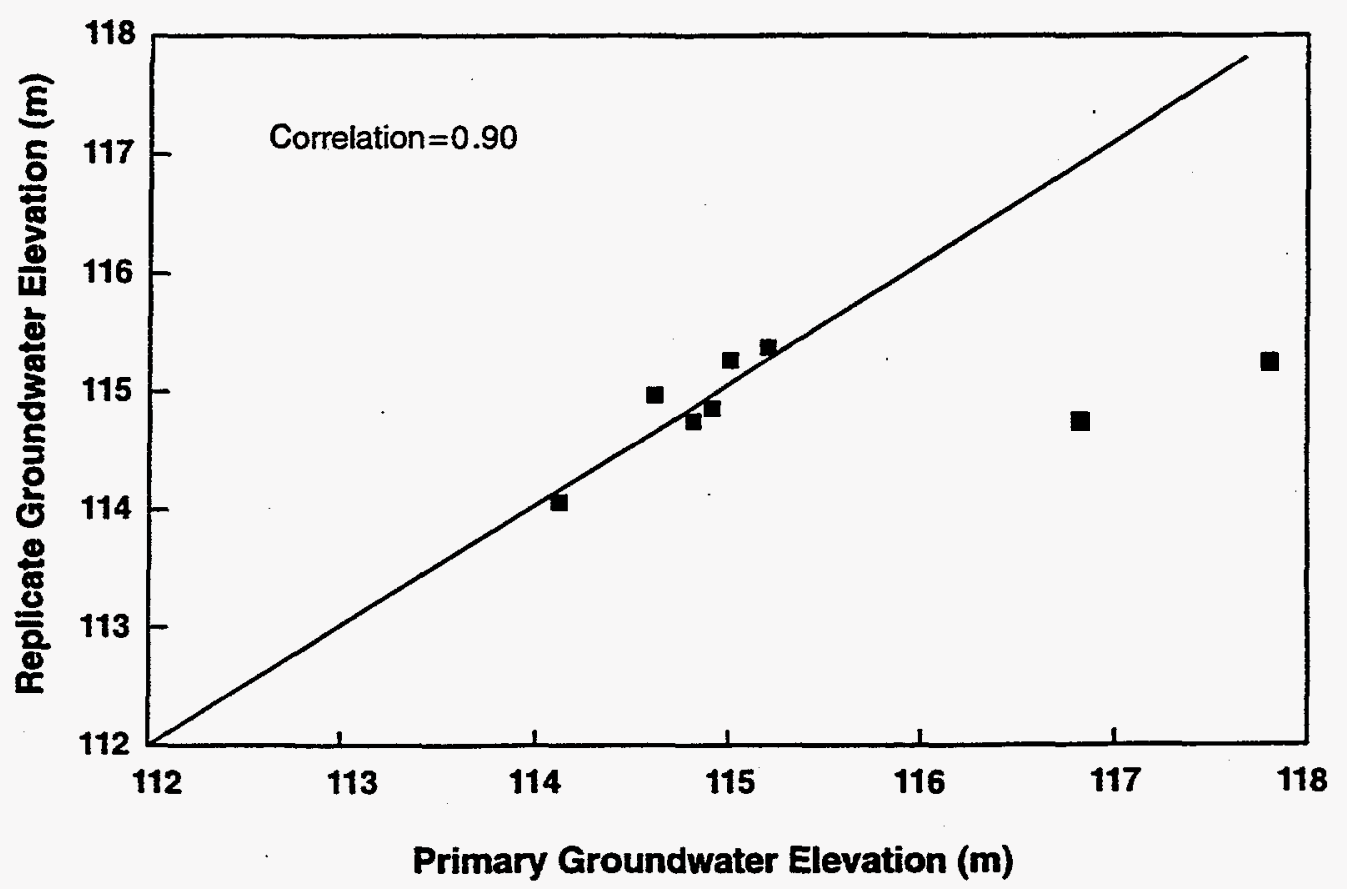

E9508071.4

\subsection{HUMAN HEALTH AND ECOLOGICAL RISK EVALUATION}

This section provides the results of a human health and ecological evaluation of TCE contamination detected in groundwater associated with the 100-FR-3 Operable Unit. The qualitative risk assessment (QRA) for the 100-FR-3 Operable Unit is an evaluation of risk for a predefined set of human and environmental scenarios. The QRA was prepared as agreed by the 100 Area Hanford Federal Facility Agreement and Consent Order (Tri-Party Agreement) unit managers using methods recommended in the Hanford Site Risk Assessment Methodology (HSRAM) (DOE-RL 1995). The COPC is limited to TCE, a VOC that dissolves in groundwater and may migrate toward the Columbia River. The information in this evaluation supplements the results from the QRA and evaluates possible changes in the conclusions presented in the original 100-FR-3 LFI.

\subsection{SUMMARY OF DATA USED}

Concentrations of TCE detected in groundwater during the supplemental LFI ranged from less than detectable $(<0.5 \mu \mathrm{g} / \mathrm{L})$ to $52 \mu \mathrm{g} / \mathrm{L}$. The highest concentration detected was used to evaluate human health risks potentially associated with TCE in groundwater. Evaluation of human health and ecological risks in the original QRA (WHC 1993) was based on a TCE concentration in groundwater of $28 \mu \mathrm{g} / \mathrm{L}$. 
DOE/RL-95-99

Rev. 0

Figure 14. Plot of Duplicate Groundwater Sample Trichloroethylene Concentrations.

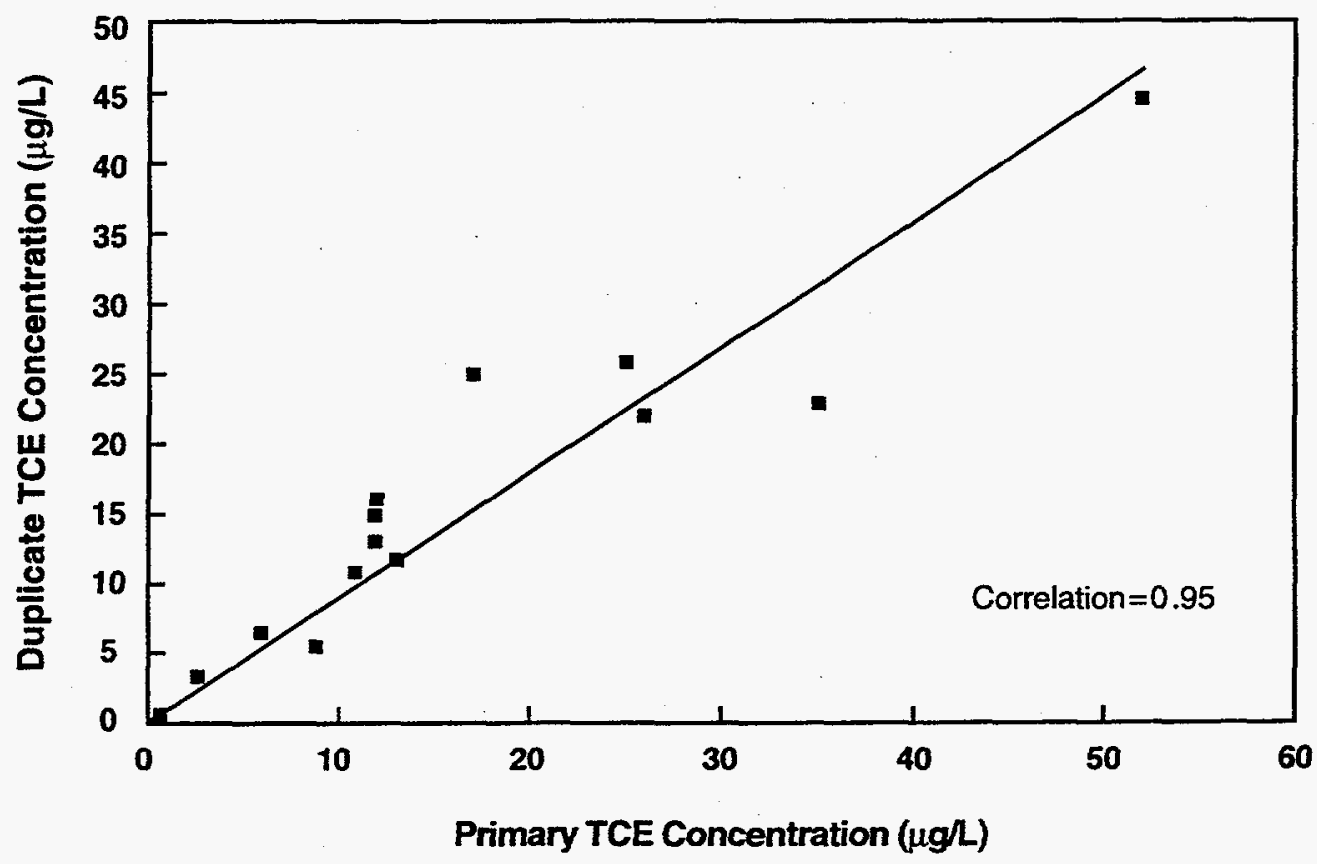

E9508071.2

Figure 15. Plot of Replicate Groundwater Sample Trichloroethylene Concentrations.

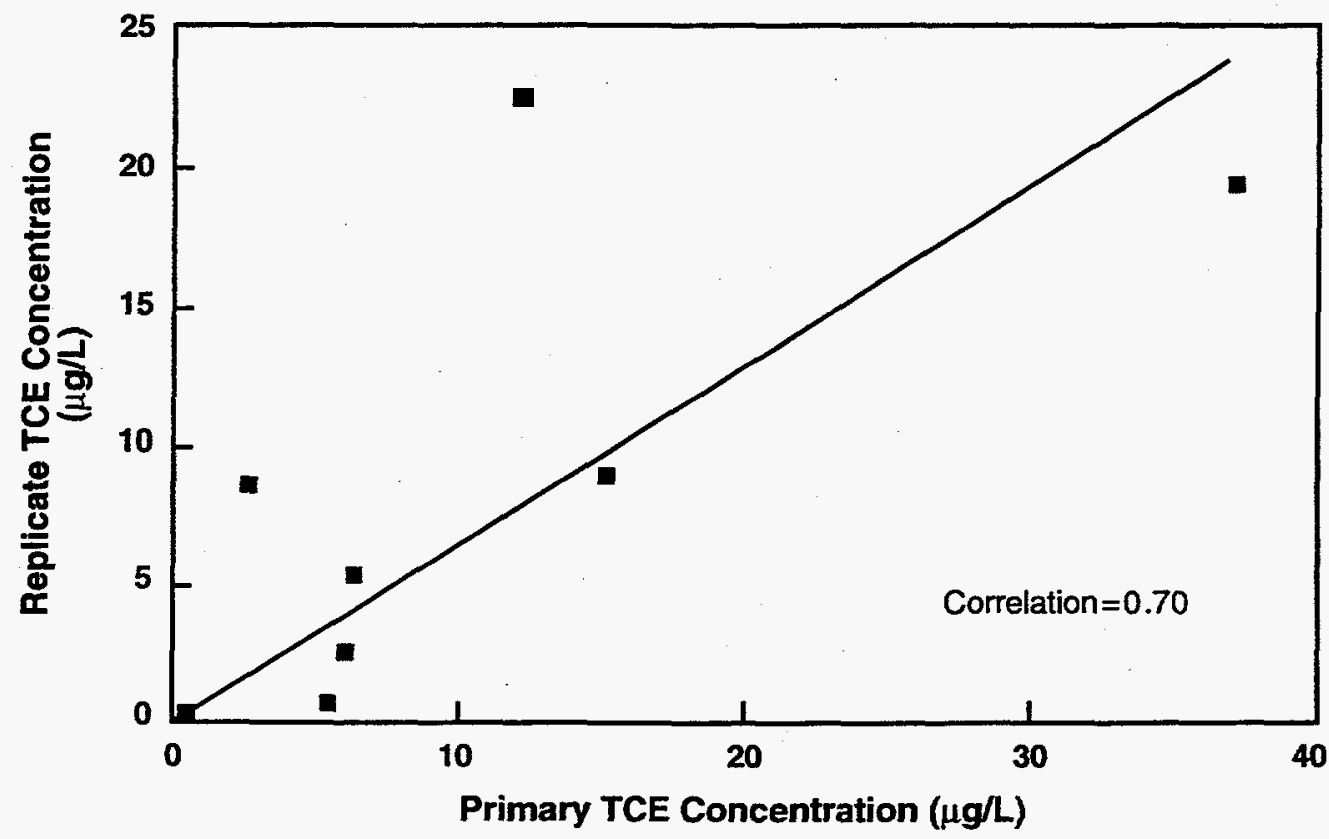

E9508071.3 
DOE/RL-95-99

Rev. 0

\subsection{HUMAN HEALTH EVALUATION}

\subsubsection{Overview of Human Health Evaluation Process}

This human health evaluation used the same assumptions and methods as the QRA. Two exposure scenarios (frequent and occasional use) and two pathways (groundwater ingestion of contaminants and inhalation of VOC from groundwater use) were evaluated in the QRA. The frequent-use and occasional-use scenarios were evaluated using residential and recreational exposure parameters from HSRAM (DOE-RL 1995). The occasional-use scenario was evaluated for illustrative purposes only. In actual practice, the human use of groundwater that exceeds drinking water standards would not be allowed, even if such use were only occasional. Currently, there is no human use of groundwater in the 100-FR-3 Operable Unit. The ingestion pathway was evaluated for both frequent-use and occasional-use scenarios.

\subsubsection{Summary and Conclusion}

The results from the original QRA indicated that the noncarcinogenic health quotient (HQ) for $28 \mu \mathrm{g} / \mathrm{L}$ of TCE in groundwater did not exceed 1.0. Reevaluation of the HQ with the revised exposure concentration of $52 \mu \mathrm{g} / \mathrm{L}$ did not change the conclusion from the QRA that noncarcinogenic effects were not of concern for TCE in groundwater associated with the 100-FR-3 Operable Unit.

The qualitative risk estimates for carcinogenic effects presented in the QRA are assigned levels of high (incremental cancer risk [ICR] $\geq 1$ E-02), medium ( $1 \mathrm{E}-04 \leq \mathrm{ICR}<1 \mathrm{E}-02)$, low $(1 \mathrm{E}-06 \leq \mathrm{ICR}<1$ E-04), and very low (ICR $<1$ E-06). In general, the risk is two orders of magnitude lower (one level) for the occasional-use than for the frequent-use scenario. This is true because the only difference in the risk calculations is the exposure frequency ( 7 days/yr for occasional use versus 365 days/yr for frequent use). This rule of thumb will hold except when a contaminant has both an oral and an inhalation slope factor. If this is the case, the risk is summed across pathways for the frequent-use scenario, but only the ingestion risk applies for the occasional-use scenario.

Under the frequent-use (residential) scenario, the ICR associated with $52 \mu \mathrm{g} / \mathrm{L}$ TCE in groundwater was $2.12 \times 10^{-5}$. The ICR associated with $28 \mu \mathrm{g} / \mathrm{L}$ TCE in groundwater, originally calculated in the QRA, was $1.15 \times 10^{-5}$. TCE was rated as a low risk in the QRA. The results from this evaluation with the additional data in groundwater did not result in any changes to this rating. Similarly, the QRA concluded that risks from TCE in groundwater were ranked as low under the occasional- (recreational) use scenario. The results from this evaluation with the additional data in groundwater did not result in any changes to this rating.

\subsection{ECOLOGICAL RISK EVALUATION}

\subsubsection{Overview of the Ecological Risk Evaluation Process}

The ecological receptors used in this evaluation, according to the protocol developed in the HSRAM (DOE-RL 1995) for groundwater operable units, includes aquatic and riparian organisms expected to live in, or that are associated with, the Columbia River. The likelihood of an adverse effect from TCE on one or more of the potential receptors is expressed in the form of an Environmental Hazard Quotient (EHQ). The EHQ, in this case, is defined as the ratio of the TCE concentration in groundwater as it flows into and mixes with the Columbia River to a lowest observable adverse effect level (LOAEL). A 
potential ecological risk is indicated if the EHQ exceeds 1.0. The LOAEL used for TCE is the acute Ambient Water Quality Criteria (AWQC) of $45,000 \mu \mathrm{g} / \mathrm{L}$ (EPA 1986). There is no chronic AWQC for TCE, but experiments with aquatic receptors indicate that observable adverse effects under chronic exposure conditions may occur at levels around $21,900 \mu \mathrm{g} / \mathrm{L}$.

\subsubsection{Summary and Conclusion}

The sampling locations for this TCE supplemental LFI were within the identified plume area that is approximately $1 / 2$ mile from the Columbia River. There are no data from this study that provide TCE concentrations in groundwater near the river or as it enters the river. Therefore, the maximum groundwater concentration detected by the supplemental LFI was used to assess the ecological risks to receptors near the Columbia River. This approach is conservative and it overestimates the risks, but is appropriate as a screening tool to determine a conservative upper risk boundary. Using the maximum TCE concentration detected in groundwater $(52 \mu \mathrm{g} / \mathrm{L})$, the EHQ is several orders of magnitude below 1.0. This indicates there is no significant risk to ecological receptors in the aquatic and riparian ecosystems near the 100-FR-3 Operable Unit. This conclusion is supported by the fact that TCE was not detected in the near-river wells during the earlier LFI sampling (DOE-RL 1994).

\subsection{CONCLUSIONS}

The methods used to collect and analyze soil gas and groundwater samples for TCE effectively met the DQOs of the investigation. Early in the study, the sampling apparatus did not perform adequately for measuring the depth to the water table within the accuracy and precision required for the study. This problem also negatively affected the ability to collect representative soil gas samples from the vadose zone. As this problem was observed, the sampling apparatus (and to a minor extent, the sampling methodology) was modified in order to meet the objectives of the study. The results of quality assurance/quality control samples collected after the sampling equipment were modified to support the conclusion that the modified method was successful and met the objectives of the investigation.

Using groundwater elevation measurements obtained from nine groundwater monitoring wells in the study area and selected elevations obtained using the groundwater probes, the site conceptual model was refined in relation to the movement of groundwater in the study area. Groundwater movement in the region was found to flow predominantly to the northeast. Groundwater movement appears to assume a more easterly flow direction as it approaches and is influenced by the Columbia River. These findings are supported by earlier models of groundwater movement in the study area.

The concentration of TCE in shallow groundwater was characterized in accordance with the stated DQOs for the study. A groundwater plume containing TCE concentrations in excess of EPA and Ecology drinking water standards in the 100-FR-3 Operable Unit was identified and delineated. The highest groundwater TCE concentration detected was $52 \mu \mathrm{g} / \mathrm{L}$. The TCE concentration detected in groundwater in this region is consistent with the levels of TCE detected in groundwater monitoring wells 699-77-36 and 199-F7-1. The results from a set of samples collected to determine TCE levels in deeper portions of the aquifer were inconclusive.

The concentration of TCE in the vadose zone was adequately characterized in accordance with the DQOs for the study. Problems with the sampling equipment early in the study resulted in some 
unrepresentative soil gas samples. The results of these samples were eliminated from the data set. This may have negatively affected the usefulness of the soil gas data. Relatively low concentrations of TCE were detected in soil gas collected from the vadose zone throughout the study area. The highest concentration of TCE detected in soil gas was $77 \mathrm{ppb}-\mathrm{v}$. The regions of elevated soil gas detected in the vadose zone did not appear to coincide with potential or observed sources of TCE contamination in the study area.

The soil gas TCE concentrations did not show a positive correlation with groundwater TCE concentrations measured at each sampling location. However, the lateral extent of TCE contamination in the vadose zone correlated directly with the lateral extent of the TCE plume in the underlying groundwater. In addition, the zones of elevated soil gas TCE concentrations were found to be located upgradient and adjacent to zones of elevated TCE in the groundwater. This observation may indicate that TCE in the vadose zone is being dissolved into the shallow groundwater as it moves through a region containing elevated levels of TCE in the soil gas. The absence of any observed or detected source of underground TCE contamination supports this hypothesis.

Finally, a human health and ecological risk assessment based on the data collected during this study and information reported earlier for the 100-FR-3 Operable Unit categorized the risk to human, riparian, or aquatic organisms from the levels of TCE detected in the groundwater associated with the 100-FR-3 Operable Unit as "low risk."

\subsection{REFERENCES}

BHI, 1994a, Environmental Analytical Laboratory Operations Procedures, BHI-EE-04, Bechtel Hanford, Inc., Richland, Washington.

BHI, 1994b, Environmental Investigations Procedures, BHI-EE-01, Bechtel Hanford, Inc., Richland, Washington.

BHI, 1994c, Historical Background Information of the White Bluffs Pickling Acid Crib Area, BHI-00049, Rev. 00, Bechtel Hanford, Inc., Richland, Washington.

BHI, 1995a, 100-FR-3 Groundwater/Soil-Gas Supplementary Limited Field Investigation Description of Work, BHI-00322, Rev. 00, Bechtel Hanford, Inc., Richland, Washington.

BHI, 1995b, Field Screening Procedures, BHI-EE-05, Bechtel Hanford, Inc., Richland, Washington.

DOE-RL, 1994, Limited Field Investigation Report for the 100-FR-3 Operable Unit, DOE/RL-93-83, Draft A, U.S. Department of Energy, Richland Operations Office, Richland, Washington.

DOE-RL, 1995, Hanford Site Risk Assessment Methodology, DOE/RL-91-45, Rev. 3, U.S. Department of Energy, Richland Operations Office, Richland, Washington.

EPA, 1986, Quality Criteria for Water 1986, EPA/540/1-89/002, U.S. Environmental Protection Agency, Office of Water Regulation and Standards, Washington, D.C. 
DOE/RL-95-99

Rev. 0

PNL, 1994, Hanford Site Environmental Report for Calendar Year 1993, PNL-9823, Pacific Northwest Laboratory, Richland, Washington.

Sittig, M., 1985, Handbook of Toxic and Hazardous Chemicals and Carcinogens, 2nd edition, Noyles Publications, Park Ridge, New Jersey.

WHC, 1993, Qualitative Risk Assessment for the 100-FR-3 Operable Unit, WHC-SD-EN-RA-012, Rev. 0, Westinghouse Hanford Company, Richland, Washington.

WHC, 1994, Geology of the 100-FR-3 Operable Unit, Hanford Site, South Central Washington, WHC-SD-EN-TI-221, Rev. 0, Westinghouse Hanford Company, Richland, Washington. 
DOE/RL-95-99

Rev. 0

APPENDIX A

ANALYTICAL DATA 
Table A-1. Soil Gas Results for the 100-FR-3 Groundwater/Soil Gas Supplemental Limited Field Investigation.

\begin{tabular}{|c|c|c|c|c|c|}
\hline $\begin{array}{c}\text { Grid } \\
\text { Location }\end{array}$ & $\begin{array}{c}\text { HEIS } \\
\text { Number }\end{array}$ & $\begin{array}{l}\text { Sample } \\
\text { Date }\end{array}$ & $\begin{array}{c}\text { Sample Depth } \\
\text { bgs }(m)\end{array}$ & $\begin{array}{l}\text { Trichloroethylene } \\
(p p b-v)\end{array}$ & $\begin{array}{l}\text { Toluene } \\
\text { (ppb-v) }\end{array}$ \\
\hline 2 & B0D6G9 & $4 / 19 / 95$ & 5.6 & $<2.0$ & $<2.0$ \\
\hline 4 & BOD6F6 & $4 / 18 / 95$ & 5.5 & $<2.0$ & $<2.0$ \\
\hline 5 & BOFHD6 & $5 / 11 / 95$ & 6.7 & 3.5 & 6.7 \\
\hline 6 & BOFH97 & $5 / 3 / 95$ & 5.5 & $<2.0$ & $<2.0$ \\
\hline 7 & BOD6J3 & $4 / 21 / 95$ & 6.1 & $<2.0$ & $<2.0$ \\
\hline 8 & BOD6G5 & $4 / 19 / 95$ & 2.4 & 3.8 & $<2.0$ \\
\hline 11 & BOFH99 & $5 / 3 / 95$ & 6.1 & 6.9 & $<2.0$ \\
\hline 12 & BOFC58 & $5 / 1 / 95$ & 5.5 & 7.4 & $<2.0$ \\
\hline 13 & BOFC56 & $5 / 1 / 95$ & 4.6 & 12 & 5.5 \\
\hline 15 & BOFBZ1 & $4 / 24 / 95$ & 5.9 & 7.9 & 4.9 \\
\hline 16 & BOD6J7 & $4 / 21 / 95$ & 4.7 & 32 & $<2.0$ \\
\hline 17 & BOFHF2 & $5 / 11 / 95$ & 6.8 & 12 & $<2.0$ \\
\hline 18 & $\mathrm{BOFHCO}$ & $5 / 10 / 95$ & 7.1 & 31 & $<2.0$ \\
\hline 19 & BOFC46 & $4 / 28 / 95$ & 5.2 & $<2.0$ & $<2.0$ \\
\hline 20 & BOFBZ3 & $4 / 24 / 95$ & 6.1 & $<2.0$ & $<2.0$ \\
\hline 21 & $\mathrm{BOFCO} 3$ & $4 / 25 / 95$ & 6.2 & 9.5 & 6.8 \\
\hline $21 N$ & BOFKM9 & $5 / 17 / 95$ & 6.2 & 6.8 & $<2.0$ \\
\hline 22 & BOFC06 & $4 / 25 / 95$ & 9.6 & 31 & $<2.0$ \\
\hline $22 W$ & BOFC17 & $4 / 26 / 95$ & 6.1 & 69 & 6.0 \\
\hline 23 & BOFC33 & $4 / 27 / 95$ & 3.9 & 13 & $<2.0$ \\
\hline 24 & BOFC44 & $5 / 1 / 95$ & 1.5 & 63 & 8.4 \\
\hline 25 & $\mathrm{BOFCO} 2$ & $4 / 25 / 95$ & 7.9 & $<2.0$ & 11 \\
\hline 26 & BOFKK4 & $5 / 15 / 95$ & 4.3 & 32 & $<2.0$ \\
\hline 28 & BOFC 31 & $4 / 27 / 95$ & 5.0 & 77 & $<2.0$ \\
\hline 29 & BOFKL7 & $5 / 16 / 95$ & 2.5 & 6.5 & $<2.0$ \\
\hline 30 & BOFKN1 & $5 / 17 / 95$ & 7.6 & $<2.0$ & 8.4 \\
\hline 31 & BOFKK 7 & $5 / 15 / 95$ & 4.2 & 36 & 4.9 \\
\hline $31 \mathrm{~N}$ & BOFKN9 & $5 / 19 / 95$ & 4.0 & $<2.0$ & $<2.0$ \\
\hline 32 & BOFKJ2 & $5 / 12 / 95$ & 6.9 & 8.4 & $<2.0$ \\
\hline 33 & BOFHF8 & $5 / 12 / 95$ & 5.1 & 40 & 13 \\
\hline 34 & BOG $4 S 1$ & $6 / 28 / 95$ & 4.7 & 31 & 3.4 \\
\hline 35 & BOFKL9 & $5 / 16 / 95$ & 6.4 & $<2.0$ & 7.4 \\
\hline 38 & BOFHC6 & $5 / 10 / 95$ & 5.5 & 3.8 & $<2.0$ \\
\hline 40 & BOG4O7 & $6 / 27 / 95$ & 4.5 & $<2.0$ & $<2.0$ \\
\hline 41 & BOFKW1 & $6 / 22 / 95$ & 2.4 & 68 & $<2.0$ \\
\hline 42 & BOFKW2 & $6 / 22 / 95$ & 6.3 & 35 & $<2.0$ \\
\hline 43 & BOFKX 2 & $6 / 23 / 95$ & 6.2 & 22 & $<2.0$ \\
\hline 44 & BOFKX6 & $6 / 23 / 95$ & 5.7 & 14 & $<2.0$ \\
\hline 45 & BOG4O4 & $6 / 27 / 95$ & 3.7 & $<2.0$ & $<2.0$ \\
\hline 47 & BOG401 & $6 / 27 / 95$ & 6.6 & $<2.0$ & $<2.0$ \\
\hline 49 & BOFKX9 & $6 / 23 / 95$ & 4.6 & 7.2 & $<2.0$ \\
\hline
\end{tabular}


Table A-2. Groundwater Elevation Measurements for the 100-FR-3 Groundwater/Soil Gas Supplemental Limited Field Investigation.

\begin{tabular}{|c|c|c|c|c|}
\hline $\begin{array}{c}\text { Grid } \\
\text { Location }\end{array}$ & $\begin{array}{c}\text { Easting } W S P \\
\text { Coordinate }(m)\end{array}$ & $\begin{array}{l}\text { Northing WSP } \\
\text { Coordinate }(m)\end{array}$ & $\begin{array}{c}\text { Surface } \\
\text { Elevation }(m)\end{array}$ & $\begin{array}{l}\text { Groundwate } \\
\text { Elevation }(m)\end{array}$ \\
\hline 2 & 577375.47 & 147937.75 & 125.4 & 115.7 \\
\hline 4 & 578104.05 & 147965.12 & 123.7 & 116.5 \\
\hline 5 & 578405.73 & 147922.90 & 124.7 & 116.0 \\
\hline 7 & 577372.76 & 147574.80 & 125.1 & 117.8 \\
\hline 8 & 577742.01 & 147591.98 & 124.8 & 117.1 \\
\hline 9 & 578110.54 & 147604.82 & 123.7 & 116.8 \\
\hline 10 & 578467.27 & 147598.53 & 123.7 & 116.1 \\
\hline 11 & 578864.42 & 147612.93 & 123.5 & 113.8 \\
\hline 12 & 579206.91 & 147590.33 & 122.4 & 113.8 \\
\hline 13 & 579663.56 & 147686.30 & 119.4 & 113.6 \\
\hline 15 & 578117.99 & 147225.20 & 122.8 & 115.3 \\
\hline 16 & 578480.79 & 147237.36 & 123.9 & 115.7 \\
\hline 18 & 579220.31 & 147264.26 & 123.9 & 114.1 \\
\hline 19 & 579620.84 & 147308.84 & 118.4 & 113.4 \\
\hline $21 \mathrm{~N}$ & 578324.16 & 147034.94 & 121.1 & 115.2 \\
\hline $22 W$ & 578693.89 & 146867.21 & 125.5 & 115.6 \\
\hline 23 & 579201.27 & 146916.31 & 123.2 & 114.8 \\
\hline 24 & 579559.33 & 146974.81 & 117.0 & 114.8 \\
\hline 25 & 578117.75 & 146522.98 & 124.3 & 112.5 \\
\hline 26 & 578458.35 & 146483.68 & 120.3 & 115.4 \\
\hline 27 & 578830.91 & 146574.55 & 121.7 & 115.0 \\
\hline 28 & 579230.00 & 146537.99 & 120.3 & 114.6 \\
\hline 29 & 579559.14 & 146600.07 & 119.7 & 114.8 \\
\hline 30 & 578474.53 & 146089.03 & 123.0 & 115.0 \\
\hline 31 & 578874.75 & 146144.58 & 119.8 & 115.2 \\
\hline $31 N$ & 578652.20 & 146391.46 & 119.4 & 115.3 \\
\hline $315 W$ & 578842.49 & 146097.90 & 119.2 & 114.8 \\
\hline 32 & 579156.16 & 146236.56 & 122.7 & 114.9 \\
\hline 33 & 579604.66 & 146185.97 & 122.4 & 114.7 \\
\hline 38 & 579142.09 & 147987.33 & 122.2 & 115.2 \\
\hline 40 & 578112.02 & 145776.40 & 120.2 & 115.2 \\
\hline 41 & 578545.52 & 145797.38 & 118.2 & 115.3 \\
\hline 42 & 578906.36 & 145806.48 & 121.6 & 114.9 \\
\hline 43 & 579210.02 & 145773.66 & 122.5 & 114.8 \\
\hline 44 & 579630.94 & 145903.08 & 121.5 & 114.7 \\
\hline 45 & 578201.96 & 145499.59 & 119.8 & 115.2 \\
\hline 47 & 578931.28 & 145477.91 & 123.2 & 114.9 \\
\hline 49 & 579635.25 & 145494.06 & 121.3 & 114.4 \\
\hline Well 199-F7-1 & 579687.17 & 147022.43 & 119.4 & 114.8 \\
\hline Well 199-F7-3 & 579884.71 & 147112.53 & 120.5 & 114.7 \\
\hline Well 699-77-36 & 578847.21 & 146868.94 & 126.7 & 116.0 \\
\hline Well 699-69-38 & 578262.52 & 144396.94 & 129.6 & 123.9 \\
\hline Well 699-69-45 & 576157.41 & 144556.31 & 148.6 & 122.2 \\
\hline Well 699-62-43E & 576878.22 & 142492.05 & 129.6 & 120.1 \\
\hline Well 699-81-38 & 578172.35 & 148241.56 & 124.9 & 116.4 \\
\hline Well 699-80-43S & 576701.92 & 147774.69 & 126.8 & 119.0 \\
\hline Well 699-74-44 & 576393.09 & 146098.78 & 136.7 & 121.7 \\
\hline Well 699-71-30 & 580603.35 & 145226.91 & 123.1 & 113.9 \\
\hline
\end{tabular}


DOE/RL-95-99

Rev. 0

Table A-3. Groundwater Results for the 100-FR-3 Groundwater/Soil Gas Supplemental Limited Field Investigation.

\begin{tabular}{|c|c|c|c|c|c|}
\hline $\begin{array}{c}\text { Grid } \\
\text { Location }\end{array}$ & $\begin{array}{c}\text { HEIS } \\
\text { Number }\end{array}$ & $\begin{array}{c}\text { Sample } \\
\text { Date }\end{array}$ & $\begin{array}{c}\text { Sample Depth } \\
\text { bgs }(m)\end{array}$ & $\begin{array}{c}\text { Trichloroethylene } \\
(\mu \mathrm{g} / \mathrm{L})\end{array}$ & $\begin{array}{c}\text { Toluene } \\
(\mu g / L)\end{array}$ \\
\hline 2 & B006G8 & $4 / 19 / 95$ & 10.1 & $<0.50$ & $<0.50$ \\
\hline 4 & BOD6F5 & $4 / 18 / 95$ & 9.1 & $<0.50$ & $<0.50$ \\
\hline 5 & BOFKT1 & $5 / 24 / 95$ & 10.4 & $<0.50$ & $<0.50$ \\
\hline 7 & BOD6H1 & $4 / 19 / 95$ & 11.3 & 0.50 & $<0.50$ \\
\hline 8 & BOD6G1 & $4 / 19 / 95$ & 10.1 & 6.7 & 0.60 \\
\hline 9 & BOD6H8 & $4 / 21 / 95$ & 9.1 & 5.4 & $<0.50$ \\
\hline 10 & BOFHB4 & $5 / 9 / 95$ & 8.5 & 6.6 & $<0.50$ \\
\hline 11 & BOFHB8 & $5 / 10 / 95$ & 9.8 & 9.2 & $<0.50$ \\
\hline 12 & BOFH91 & $5 / 2 / 95$ & 8.8 & 26 & $<0.50$ \\
\hline 13 & BOFC57 & $5 / 1 / 95$ & 6.4 & 2.0 & $<0.50$ \\
\hline 15 & BOD6K 6 & $4 / 24 / 95$ & 8.5 & 0.75 & 0.60 \\
\hline 16 & BOFHFO & $5 / 11 / 95$ & 10.1 & 8.9 & $<0.50$ \\
\hline 18 & BOFKL4 & $5 / 10 / 95$ & 10.7 & 8.8 & $<0.50$ \\
\hline 19 & BOFC 49 & $5 / 1 / 95$ & 6.1 & 25 & 0.50 \\
\hline $21 N$ & BOFKNO & $5 / 16 / 95$ & 7.0 & 0.98 & $<0.50$ \\
\hline $22 W$ & BOFC23 & $4 / 27 / 95$ & 11.0 & 13 & $<0.50$ \\
\hline 23 & BOFC 37 & $4 / 28 / 95$ & 9.1 & 12 & 0.80 \\
\hline 24 & BOFC 53 & $5 / 1 / 95$ & 3.0 & 20 & $<0.50$ \\
\hline 25 & BOFCO1 & $4 / 25 / 95$ & 13.1 & $<0.50$ & 0.92 \\
\hline 26 & BOFKK 1 & $5 / 15 / 95$ & 7.0 & 6.0 & 1.8 \\
\hline 27 & BOFC29 & $4 / 27 / 95$ & 10.1 & 33 & 1.1 \\
\hline 28 & BOFC 32 & $4 / 27 / 95$ & 6.4 & 15 & 0.90 \\
\hline 29 & B0D6D8 & $4 / 18 / 95$ & 8.2 & 11 & $<0.50$ \\
\hline 30 & BOFKN8 & $5 / 17 / 95$ & 8.8 & 3.4 & $<0.50$ \\
\hline 31 & BOFKK 8 & $5 / 15 / 95$ & 5.8 & 52 & $<0.50$ \\
\hline $37 N$ & BOFKS1 & $5 / 19 / 95$ & 5.0 & 11 & $<0.50$ \\
\hline $31 \mathrm{SW}$ & BOG $4 S 4$ & $6 / 28 / 95$ & 5.2 & 26 & $<0.50$ \\
\hline 32 & BOG $4 R 4$ & $6 / 27 / 95$ & 8.8 & 23 & $<0.50$ \\
\hline 33 & BOFKJO & $5 / 12 / 95$ & 8.5 & 35 & $<0.50$ \\
\hline 38 & BOFHC7 & $5 / 10 / 95$ & 7.9 & 1.1 & $<0.50$ \\
\hline 40 & BOG409 & $6 / 27 / 95$ & 5.8 & $<0.50$ & $<0.50$ \\
\hline 41 & BOFKV8 & $6 / 22 / 95$ & 4.0 & 6.3 & $<0.50$ \\
\hline 42 & BOFKW5 & $6 / 22 / 95$ & 7.6 & 7.8 & $<0.50$ \\
\hline 43 & BOFK $\times 4$ & $6 / 23 / 95$ & 8.2 & 15 & $<0.50$ \\
\hline 44 & BOFKX7 & $6 / 23 / 95$ & 7.6 & 11 & $<0.50$ \\
\hline 45 & BOG4Q6 & $6 / 27 / 95$ & 5.8 & $<0.50$ & $<0.50$ \\
\hline 47 & BOG 403 & $6 / 27 / 95$ & 8.8 & $<0.50$ & $<0.50$ \\
\hline 49 & BOG4P7 & $6 / 23 / 95$ & 7.3 & $<0.50$ & $<0.50$ \\
\hline Well 199-F7-1 & BOFK 54 & $5 / 18 / 95$ & 4.6 & 24 & $<0.50$ \\
\hline Well 199-F7-3 & BOFK 55 & $5 / 23 / 95$ & 5.8 & 1.7 & $<0.50$ \\
\hline Well 699-77-36 & BOFK56 & $5 / 16 / 95$ & 10.7 & 20 & $<0.50$ \\
\hline Well 699-81-38 & BOFK 60 & $5 / 31 / 95$ & 8.5 & $<0.50$ & $<0.50$ \\
\hline Well 699-80-43S & BOFK 59 & $6 / 6 / 95$ & 7.8 & $<0.50$ & $<0.50$ \\
\hline Well 699-74-44 & BOFK57 & $5 / 31 / 95$ & 15.0 & $<0.50$ & $<0.50$ \\
\hline Well 699-71-30 & BOFK 58 & $6 / 6 / 95$ & 9.2 & $<0.50$ & $<0.50$ \\
\hline
\end{tabular}


Table A-4. Duplicate and Replicate Soil Gas Results for the 100-FR-3 Groundwater/Soil Gas Supplemental Limited Field Investigation.

\begin{tabular}{|c|c|c|c|c|c|}
\hline $\begin{array}{c}\text { Grid } \\
\text { Location }\end{array}$ & $\begin{array}{c}\text { Sample } \\
\text { Type }\end{array}$ & $\begin{array}{c}\text { HEIS } \\
\text { Number }\end{array}$ & $\begin{array}{c}\text { Sample } \\
\text { Date }\end{array}$ & $\begin{array}{c}\text { Sample Depth } \\
\text { bgs }(m)\end{array}$ & $\begin{array}{c}\text { Trichloroethylene } \\
(p p b-v)\end{array}$ \\
\hline 4 & Primary & BOD6F6 & $4 / 18 / 95$ & 5.5 & $<2.0$ \\
4 & Duplicate & BOD6F7 & $4 / 18 / 95$ & 5.5 & $<2.0$ \\
5 & Primary & BOFHD6 & $5 / 11 / 95$ & 6.7 & 3.5 \\
$5 R$ & Replicate & BOFKS8 & $5 / 24 / 95$ & 6.7 & 3.7 \\
7 & Primary & BOD6H2 & $4 / 19 / 95$ & 8.0 & $<2.0$ \\
$7 R$ & Replicate & BOD6J3 & $4 / 21 / 95$ & 6.1 & $<2.0$ \\
20 & Primary & BOFBZ4 & $4 / 24 / 95$ & 2.4 & $<2.0$ \\
$20 R$ & Replicate & BOFBZ3 & $4 / 24 / 95$ & 6.1 & $<2.0$ \\
21 & Primary & BOFCO3 & $4 / 25 / 95$ & 6.2 & 9.5 \\
21 & Duplicate & BOFCO4 & $4 / 25 / 95$ & 6.2 & 9.7 \\
22 & Primary & BOFCO7 & $4 / 25 / 95$ & 2.4 & 41 \\
$22 R$ & Replicate & BOFCO6 & $4 / 25 / 95$ & 9.6 & 31 \\
$22 W$ & Primary & BOFC18 & $4 / 26 / 95$ & 2.4 & 64 \\
$22 W R$ & Replicate & BOFC17 & $4 / 26 / 95$ & 6.1 & 69 \\
32 & Primary & BOFKJ2 & $5 / 12 / 95$ & 6.9 & 8.4 \\
32 & Duplicate & BOFKJ3 & $5 / 12 / 95$ & 6.9 & 17 \\
35 & Primary & BOFKL9 & $5 / 16 / 95$ & 6.4 & $<2.0$ \\
35 & Duplicate & BOFKMO & $5 / 16 / 95$ & 6.4 & 2.6 \\
40 & Primary & BOG4O7 & $6 / 27 / 95$ & 4.5 & $<2.0$ \\
40 & Duplicate & BOG4O8 & $6 / 27 / 95$ & 4.5 & $<2.0$ \\
42 & Primary & BOFKW2 & $6 / 22 / 95$ & 6.3 & 35 \\
42 & Duplicate & BOFKW3 & $6 / 22 / 95$ & 6.3 & 30 \\
\hline
\end{tabular}


Rev. 0

Table A-5. Replicate Groundwater Elevation Measurements for the 100-FR-3 Groundwater/Soil Gas Supplemental Limited Field Investigation.

\begin{tabular}{|c|c|c|c|}
\hline $\begin{array}{c}\text { Grid } \\
\text { Location }\end{array}$ & $\begin{array}{c}\text { Sample } \\
\text { Type }\end{array}$ & $\begin{array}{c}\text { Surface } \\
\text { Elevation }(m)\end{array}$ & $\begin{array}{c}\text { Groundwater } \\
\text { Elevation }(m)\end{array}$ \\
\hline 7 & Primary & 125.1 & 117.8 \\
7 & Replicate & 125.1 & 115.3 \\
9 & Primary & 123.7 & 116.8 \\
9 & Replicate & 123.7 & 114.8 \\
18 & Primary & 123.9 & 114.1 \\
18 & Replicate & 123.9 & 114.1 \\
24 & Primary & 117.0 & 114.8 \\
24 & Replicate & 117.0 & 114.8 \\
26 & Primary & 120.3 & 115.2 \\
26 & Replicate & 120.3 & 115.4 \\
28 & Primary & 120.3 & 114.6 \\
28 & Replicate & 120.3 & 115.0 \\
32 & Primary & 122.7 & 114.9 \\
32 & Replicate & 122.7 & 114.9 \\
41 & Primary & 118.2 & 115.0 \\
41 & Replicate & 118.2 & 115.3 \\
\hline
\end{tabular}


Table A-6. Duplicate and Replicate Groundwater Results for the 100-FR-3 Groundwater/Soil Gas Supplemental Limited Field Investigation.

\begin{tabular}{|c|c|c|c|c|c|c|}
\hline $\begin{array}{c}\text { Grid } \\
\text { Location }\end{array}$ & $\begin{array}{l}\text { Sample } \\
\text { Type }\end{array}$ & $\begin{array}{l}\text { Analyzing } \\
\text { Laboratory }\end{array}$ & $\begin{array}{c}\text { HEIS } \\
\text { Number }\end{array}$ & $\begin{array}{l}\text { Sample } \\
\text { Date }\end{array}$ & $\begin{array}{c}\text { Sample Depth } \\
\text { bgs }(m)\end{array}$ & $\begin{array}{c}\text { Trichloroethylene } \\
(\mu \mathrm{g} / \mathrm{L})\end{array}$ \\
\hline 7 & Primary & Fieid & BOD6H1 & $4 / 19 / 95$ & 11 & 0.50 \\
\hline $7 R$ & Replicate & EAL & $\mathrm{BOD} 6 \mathrm{H} 7$ & $4 / 20 / 95$ & 8.2 & $<0.50$ \\
\hline 9 & Primary & EAL & BOD6H8 & $4 / 2.1 / 95$ & 9.1 & 5.4 \\
\hline $9 R$ & Replicate & Field & BOD6J 2 & $4 / 20 / 95$ & 9.1 & 0.80 \\
\hline 12 & Primary & Field & BOFH91 & $5 / 2 / 95$ & 8.8 & 26 \\
\hline 12 & Duplicate & Field & BOFH92 & $5 / 2 / 95$ & 8.8 & 22 \\
\hline 15 & Primary & Field & BOD6K6 & $4 / 24 / 95$ & 8.5 & 0.75 \\
\hline 15 & Duplicate & EAL & BOD $6 K 7$ & $4 / 24 / 95$ & 8.5 & 0.78 \\
\hline 16 & Primary & Field & BOFHFO & $5 / 11 / 95$ & 10.1 & 8.9 \\
\hline 16 & Duplicate & EAL & BOFHF 1 & $5 / 11 / 95$ & 10.1 & 5.4 \\
\hline 18 & Primary & Field & $\mathrm{BOFHC} 2$ & $5 / 10 / 95$ & 10.7 & 2.6 \\
\hline 18 & Duplicate & Field & BOFHC3 & $5 / 10 / 95$ & 10.7 & 2.9 \\
\hline $18 R$ & Replicate & Field & BOFKL4 & $5 / 16 / 95$ & 10.7 & 8.8 \\
\hline 19 & Primary & Field & BOFC48 & $5 / 1 / 95$ & 6.1 & 17 \\
\hline 19 & Duplicate & Field & BOFC49 & $5 / 1 / 95$ & 6.1 & 25 \\
\hline $22 W$ & Primary & Field & BOFC23 & $4 / 27 / 95$ & 11.0 & 13 \\
\hline $22 W$ & Duplicate & EAL & BOFC 24 & $4 / 27 / 95$ & 11.0 & 12 \\
\hline 23 & Primary & Field & BOFC 37 & $4 / 28 / 95$ & 9.1 & 12 \\
\hline 23 & Duplicate & Field & BOFC38 & $4 / 28 / 95$ & 9.1 & 13 \\
\hline 24 & Primary & Field & BOFC45 & $4 / 28 / 95$ & 3.0 & 37 \\
\hline $24 R$ & Replicate & Field & BOFC53 & $5 / 1 / 95$ & 3.0 & 20 \\
\hline 26 & Primary & Field & BOFKK 1 & $5 / 15 / 95$ & 7.0 & 6.0 \\
\hline 26 & Duplicate & Field & BOFKK2 & $5 / 15 / 95$ & 7.0 & 6.3 \\
\hline $26 R$ & Replicate & Field & BOFKK 6 & $5 / 15 / 95$ & 6.4 & 2.7 \\
\hline 28 & Primary & Field & BOFC 32 & $4 / 27 / 95$ & 6.4 & 15 \\
\hline $28 R$ & Replicate & Field & BOG 457 & $6 / 28 / 95$ & 6.1 & 9.3 \\
\hline 30 & Primary & Field & BOFKN7 & $5 / 17 / 95$ & 8.8 & 2.6 \\
\hline 30 & Duplicate & Field & BOFKN8 & $5 / 17 / 95$ & 8.8 & 3.4 \\
\hline 31 & Primary & Field & BOFKK 8 & $5 / 15 / 95$ & 5.8 & 52 \\
\hline 31 & Duplicate & EAL & BOFKL1 & $5 / 15 / 95$ & 5.8 & 45 \\
\hline $31 \mathrm{~N}$ & Primary & Field & BOFKS1 & $5 / 19 / 95$ & 5.0 & 11 \\
\hline $31 \mathrm{~N}$ & Duplicate & Field & BOFKS2 & $5 / 19 / 95$ & 7.6 & 11 \\
\hline $31 N$ & Duplicate & EAL & BOFKS4 & $5 / 19 / 95$ & 7.6 & 8.2 \\
\hline $31 \mathrm{SW}$ & Primary & Field & BOG 453 & $6 / 28 / 95$ & 5.2 & 25 \\
\hline $31 \mathrm{SW}$ & Duplicate & Field & BOG4S4 & $6 / 28 / 95$ & 5.2 & 26 \\
\hline 32 & Primary & Field & BOFKJ5 & $5 / 12 / 95$ & 8.8 & 12 \\
\hline 32 & Duplicate & Field & BOFKJ 6 & $5 / 12 / 95$ & 8.8 & 16 \\
\hline $32 R$ & Replicate & Field & BOG4R4 & $6 / 27 / 95$ & 8.8 & 23 \\
\hline 33 & Primary & Field & BOFKJO & $5 / 12 / 95$ & 8.5 & 35 \\
\hline 33 & Duplicate & Field & BOFKJ1 & $5 / 12 / 95$ & 8.5 & 23 \\
\hline 41 & Primary & Field & BOFKV8 & $6 / 22 / 95$ & 4.0 & 6.3 \\
\hline $41 R$ & Replicate & Field & BOFKW5 & $6 / 22 / 95$ & 5.2 & 5.6 \\
\hline 43 & Primary & Field & BOFKX3 & $6 / 23 / 95$ & 8.2 & 12 \\
\hline 43 & Duplicate & Field & BOFKX 4 & $6 / 23 / 95$ & 8.2 & 15 \\
\hline
\end{tabular}


DOE/RL-95-99

Rev. 0

\section{DISTRIBUTION}

Number of Copies

ONSITE

35

G. W. Avolio (10)

H9-03

R. L. Biggerstaff

H4-80

G. R. Eidam

H0-09

C. W. Hedel

H0-17

G. C. Henckel

A. Hopkins

H4-80

I. D. Jacques (6)

H9-11

H9-10

G. K. Jaeger

H9-01

R. B. Kerkow

H9-10

T. LaFrancois

H9-03

J. A. Lerch

B1-35

W. S. Thompson

N1-28

D. K. Tyler

H9-03

D. C. Weekes

H9-11

S. G. Weiss

H9-03

R. C. Wilson

H9-01

BHI Document Control (3)

Hanford Technical Library

H0-09

Public Reading Room

P8-55

$\mathrm{H} 2-53$ 